\title{
Working Fluid Selection for Simple and Recuperative Organic Rankine Cycle Operating Under Varying Conditions: A Comparative Analysis
}

\author{
Dodeye Igbong ${ }^{1 *}$, Oku Ekpenyong Nyong ${ }^{1}$, James Enyia ${ }^{1}$, Ambrose Agba ${ }^{2}$ \\ 1 Department of Mechanical Engineering, Faculty of Engineering, Cross River University of Technology, Calabar, \\ Nigeria \\ 2 Department of Mechanical Engineering, Faculty of Engineering, University of Calabar, Nigeria \\ * Corresponding author's e-mail: dodeyeigbong@gmail.com
}

\begin{abstract}
The selection of suitable working fluid for simple and recuperative organic Rankine cycle (ORC) operating under subcritical, superheated and supercritical conditions are investigated. 11 fluids with critical temperature above $150{ }^{\circ} \mathrm{C}$ are considered as potential candidates. Performance screening parameters such as net power output, thermal efficiency, turbine sizing parameter (SP) and volumetric flow ratio (VFR), exegetic parameters like irreversibility rate, fuel depletion ratio, and improvement potential rate of exergy destruction were also evaluated. Results indicate that R600a, R236fa and R1233dz(E) demonstrated the best performance for subcritical, superheated and supercritical simple ORC, respectively. R236fa and R1233dz(E) proved more suitable for subcritical/ superheated and supercritical recuperative cycles, respectively. The system exegetic efficiency is reveal to be significantly higher in subcritical/superheated (61-65\%) cycles compared to the supercritical (35-45\%) cycle, the evaporator seen as the main source of exergy destruction, accounting for $17-37 \%$ of inlet exergy destroyed and about $8-24 \%$ in the turbine.
\end{abstract}

Keywords: organic Rankine cycle, organic working fluids, supercritical, exergy

\section{INTRODUCTION}

The rapid increase in population growth and economic development around the world are some of the major drivers accelerating the energy consumption experience in recent years. These energies consumed are mostly powered by fossil fuels, which are associated with environmental problems such as air pollution, acid rain, ozone layer depletion, and global warming due to emissions of greenhouse gases [1]. A promising approach to alleviate environmental pollution and reduce fossil fuel consumption, is the utilization of low-grade energy sources such as solar energy, geothermal resources, biomass energy, and power and process plant waste heat, for electricity generation [2,3]. Organic Rankine cycles (ORCs) are widely used for the conversion of low and medium-temperature grade waste heat to electricity. There have similar system configuration as the steam Rankine cycle, but instead of water, their working fluids are organic fluids with lower boiling temperature. The selection of working fluid is a crucial design process for ORC systems, as it determines the thermodynamic performance, stability, safety and environmental sustainability of the system.

Several research studies have been reported on the analyses and comparison of suitable working fluid selection and thermodynamic performance of ORCs. Saleh et al. [4] studied the performance of 31 pure working fluids at both subcritical and supercritical pressure on low-temperature ORCs. The working fluids with higher 


\begin{tabular}{|c|c|}
\hline \multicolumn{2}{|c|}{ Nomenclature } \\
\hline & cross-sectional area, $\mathrm{m}^{2}$ \\
\hline & specific heat, $\mathrm{kJ} / \mathrm{kg} \cdot \mathrm{K}$ \\
\hline$\dot{\mathrm{E}} x$ & exergy rate $(\mathrm{kW})$ \\
\hline $\mathrm{Ex}_{\mathrm{D}}$ & exergy destruction rate $(\mathrm{kW})$ \\
\hline & specific exergy $(\mathrm{kJ} / \mathrm{kg})$ \\
\hline & specific enthalpy $(\mathrm{kJ} / \mathrm{kg})$ \\
\hline & interest rate \\
\hline & mass flow rate $(\mathrm{kg} / \mathrm{s})$ \\
\hline & number of years of operation \\
\hline & pressure $(\mathrm{kPa})$ \\
\hline & condenser mass flow split ratio \\
\hline & specific entropy $(\mathrm{kJ} / \mathrm{kg} \cdot \mathrm{K})$ \\
\hline & temperature $(\mathrm{K})$ \\
\hline & critical Temperature $(\mathrm{K})$ \\
\hline & standard normal boiling point $(\mathrm{K})$ \\
\hline & heat transfer coefficient $\left(\mathrm{kW} / \mathrm{m}^{2} \cdot \mathrm{K}\right)$ \\
\hline & power output $(\mathrm{kW})$ \\
\hline$\dot{\mathrm{W}}_{\mathrm{ne}}$ & net power output $(\mathrm{kW})$ \\
\hline $\mathrm{h}$ & enthalpy, $\mathrm{kJ} / \mathrm{kg}$ \\
\hline IMP & exergy improvement potential, $\mathrm{kW}$ \\
\hline $\mathrm{K}$ & thermal conductivity, $\mathrm{kW} / \mathrm{m}$ \\
\hline \multicolumn{2}{|c|}{ Abbreviations } \\
\hline \multicolumn{2}{|c|}{ Cond condenser } \\
\hline \multicolumn{2}{|c|}{ Evap evaporator } \\
\hline \multicolumn{2}{|c|}{ HX heat exchanger } \\
\hline \multicolumn{2}{|c|}{ OM operation and maintenance } \\
\hline \multicolumn{2}{|c|}{ Turb turbine } \\
\hline \multicolumn{2}{|c|}{ Greek letters } \\
\hline \multicolumn{2}{|c|}{$\alpha$ absorbance } \\
\hline \multicolumn{2}{|c|}{$\gamma$ intercept factor } \\
\hline \multicolumn{2}{|c|}{$\varepsilon \quad$ emittance } \\
\hline \multicolumn{2}{|c|}{$\tau$ transmittance } \\
\hline \multicolumn{2}{|c|}{$\eta \quad$ efficiency } \\
\hline \multicolumn{2}{|c|}{$\mu \quad$ viscosity, $\mathrm{kg} / \mathrm{m} \cdot \mathrm{s}$} \\
\hline \multicolumn{2}{|c|}{$\rho$ density, $\mathrm{kg} / \mathrm{m}^{3}$} \\
\hline \multicolumn{2}{|r|}{$\sigma \quad$ Stefen-Boltzmann constant, $\mathrm{W} / \mathrm{m}^{2} \cdot \mathrm{K}^{4}$} \\
\hline \multicolumn{2}{|c|}{ Subscripts } \\
\hline \multicolumn{2}{|c|}{0 ambient condition } \\
\hline \multicolumn{2}{|c|}{ ch chemical } \\
\hline \multicolumn{2}{|c|}{ out output } \\
\hline \multicolumn{2}{|c|}{ in input } \\
\hline \multicolumn{2}{|c|}{$\mathrm{J}$ component } \\
\hline $\mathrm{ph}$ & physical \\
\hline
\end{tabular}

boiling points temperature were observed to produce better system thermal and heat recovery efficiencies. Investigation of suitable working fluids for low-temperature ORCs was also reported in [5, 6]. Lai et al. [7] studied the working fluids performance characteristics for high-temperature $\left(\mathrm{T}_{\max }\right.$ around $\left.250-300{ }^{\circ} \mathrm{C}\right)$ subcritical and supercritical ORC. Chen et al. [3] analysed 35 potential pure working fluids which were suitable for supercritical ORC. Other organic fluids like Isobutene, propane, propylene and difluoromethane have also been considered for supercritical ORC [8]. References $[9,10,11]$ are interesting studies that report the analyses and characteristics of different working fluids and selection screening for ORC applications.

ORC is a promising technology that has attracted intense research in waste heat recovery utilization and has quite varied applications. ORCs are used for seawater desalination [12, 13, $14,15]$, fuel cells [16], internal combustion engine $[17,18,19]$, combined cooling and power system [20,21], and combined heat and power (CHP) [22, 23].

This paper reviews the types of ORC working fluids, their thermophysical properties for pre-selection screening. Practical operating limits of ORC under different conditions. 11 potentially promising working fluids with a critical temperature above $150{ }^{\circ} \mathrm{C}$ were considered candidates for the pre-selection screening of suitable working fluids for simple and recuperated ORC operating under Subcritical, Superheated and Supercritical conditions. Thermal efficiency, net power output, exegetic efficiency and total exergy destruction rate were adapted as screening parameters for the selection of optimal working fluid for each ORC system configuration and operational conditions. Further analysis of the exegetic parameters for each working fluid considered is also evaluated. Thus, performing analysis of working fluid from both the first and second law of thermodynamics.

\section{WORKING FLUIDS FOR ORC}

The selection of the appropriate working fluid for the ORC system is very important because of its impact on the system thermal and exegetic efficiencies, equipment sizing, stability, safety, and environmental sustainability of the system. Usually, organic fluids with low boiling point are used as working fluids for the ORC because of their propensity to valorise low-grade heat source. 


\section{Types of organic working fluid}

Working fluids for the ORC are generally classified based on the nature of their saturated vapour curve as wet fluid, isentropic fluid and dry fluid as shown in the T-s diagram (Fig. 1). This fluid characteristic determines the application of the working fluid, the cycle performance and associated component arrangement in the ORC system $[24,25,26]$. As shown in Figure 1, wet fluids have saturated vapour curve with negative slopes, isentropic fluids have infinitely vertical slopes, and dry fluids have positive slopes. To avoid the risk of turbine blade erosion due to saturated liquid droplets impingement, wet fluids are usually superheated to superheated vapour state before turbine entry and are likely to end up as twophase fluid after turbine expansion due to partial condensation. To reduce the impact of turbine blade damage due to the presences of saturated liquid at the turbine outlet, a minimum dryness fraction condition kept above $85 \%$ should be satisfied [27]. As observed in the T-s diagram, because of the saturated vapour curve vertical slope for isentropic fluids, the saturated vapour at the turbine inlet remains saturated throughout turbine expansion. Similarly, dry fluids with a positive slope remain superheated throughout turbine expansion. However, if the fluid at the turbine outlet is "too dry", a substantial amount of superheat in the vapour is wasted in the condenser during cooling, thus resulting in additional cooling load [3]. For this scenario, recuperation is generally employed to reclaim excess heat in turbine outlet vapour for preheating the pressurised fluid entering the evaporator.

The type of working fluid selected have a significant influence on the ORC system initial investment and complexity, as often trade-offs between system performance and costs become a crucial investment decision. For example, wet fluid-based ORC systems generally require superheaters which attract increase investment, whereas this equipment is not applicable for the isentropic and dry fluid-based ORC systems.

A similar increase in investment and complexity is associated with dry fluid-based recuperative ORC systems. Therefore, isentropic fluid is widely recommended as a more suitable working fluid for energy recovery from low-grade waste heat source $[25,28,29,30,31]$. The type of

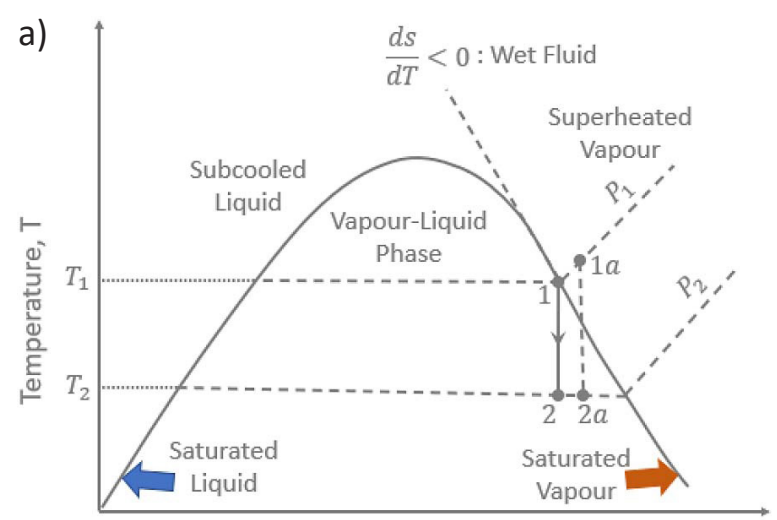

Specific Entropy, s

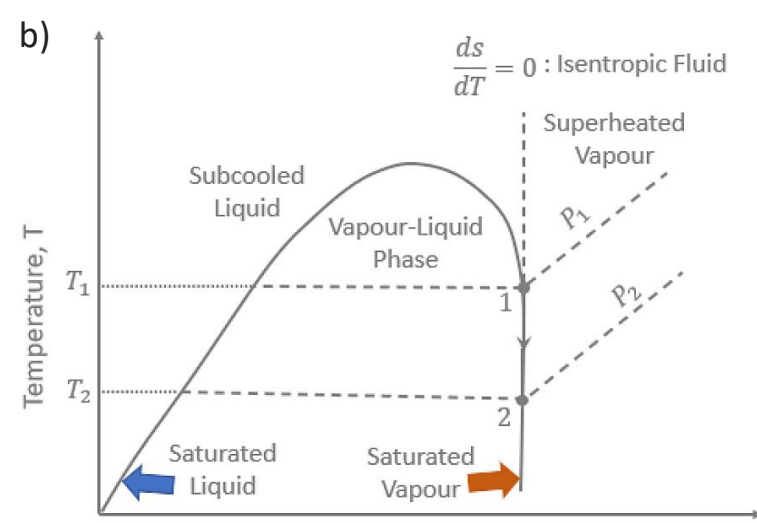

Specific Entropy, s

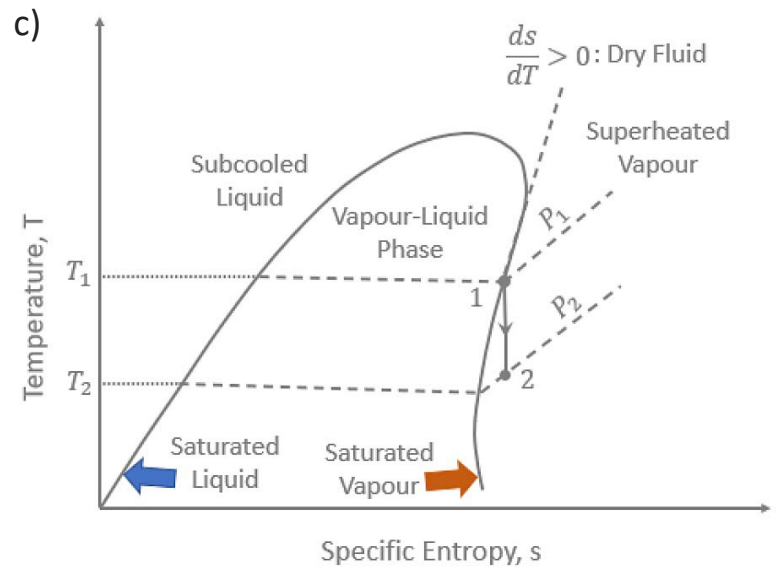

Fig. 1. T-s diagram for working fluid (a) wet fluid, (b) isentropic fluid, and (c) dry fluid 
working fluid can be determined using the method proposed to be Liu et al. [32]. This method uses ideal gas relations to derive the equation for predicting the slope of saturated vapour curve of the working fluid, as:

$$
\xi=\frac{C_{p}}{T_{H}}-\frac{\frac{n \cdot T_{r H}}{1-T_{r H}}+1}{T_{H}^{2}} \Delta h_{H}
$$

where: $T_{H}$ is the standard normal boiling point; $\Delta h_{H}$ is the change in evaporation enthalpy; $C_{p}$ is the specific heat, and $T_{r H}=T_{H} / T_{c r}$ is the ratio of a normal boiling point to critical temperature.

When the slope of the working fluid $\xi(=d s / d T)$ $>0$ : dry fluid, $\xi \approx 0$ : isentropic fluid, and $\xi<0$ : wet fluid.

\section{Working fluid pre-screening criteria}

The selection of working fluid for ORC is a function of many factors, such as the heat source temperature, ambient or coolant liquid temperature, existing environmental and safety regulations, and the working fluid properties. Therefore, some criteria used for screening potential working fluids for the ORCs are discussed in the proceeding sections.

Density of working fluid. Fluid density is very important especially for fluids with very low condensation pressure. High vapour density results in a lower volume flow rate, which leads to lower pressure losses in the heat exchanger and pipes due to reduced friction, and the consequent impact on the system turbine/expander sizing and cycle efficiency [25, 33]. However, low vapour density fluids are used where expander size is not a crucial parameter. Assuming the effect of Reynolds number is negligible, the turbine isentropic efficiency is a function of the SP and VFR [34].

The SP:

$$
S P=\frac{\sqrt{\dot{V}_{\text {out }}}}{\sqrt[4]{\Delta H_{\text {is }}}}=\frac{\sqrt{\dot{m}_{\text {out }} / \rho_{\text {out }}}}{\sqrt[4]{\Delta H_{\text {is }}}}
$$

and the VFR:

$$
V F R=\frac{\dot{V}_{\text {out }}}{\dot{V}_{\text {in }}}=\frac{\rho_{\text {in }}}{\rho_{\text {out }}}
$$

Higher SP value leads to a larger turbine size. The vapour density has an inverse relation with the SP value. Low values of VFR on the other hand, result in high cycle efficiency due to high thermal conductivity in the heat exchanger $[34,35]$.

Viscosity of working fluid. Low viscosity at both liquid and vapour state is required for high heat transfer coefficient and lower frictional losses in the heat exchanger and pipes.

Thermal conductivity. High thermal conductivity is associated with a high heat transfer coefficient in the heat exchanger.

Molecular weight. Most organic fluids are characterized as complex molecules with a heavyweight. Molecular weight has an inverse relation with turbine expansion work, which means turbine design for high molecular weight fluids tends to have low rotating speed and a small number of stages, with a consequent positive impact on turbine efficiency $[24,36]$. Also, ORC systems operating fluids with high molecular weight and high critical pressure often require a large heat transfer area [37].

Molecular complexity. Molecular complexity is another parameter that directly relates to whether the working fluid is wet, dry or isentropic, by predicting the slope of the saturated vapour curve [38].

The equation is defined as:

$$
\sigma=\frac{T_{c r}}{R}\left(\frac{\delta S}{\delta T}\right)_{S V, T_{r}=0.7}
$$

The effect of value for saturated vapour and ideal gas is evaluated as:

$$
\begin{aligned}
& \sigma=\frac{T_{c r}}{R}\left[\left(\frac{\delta S}{\delta T}\right)_{T}\left(\frac{\delta S}{\delta T}\right)_{S V}+\left(\frac{\delta S}{\delta T}\right)_{P}\right]_{S V, T_{r}=0.7} \\
& =\frac{T_{c r}}{R}\left[-\frac{R}{P}\left(\frac{\delta P}{\delta T}\right)_{S V}+\frac{C_{P}^{0}}{T}\right]_{S V, T_{r}=0.7} \\
& =\left[-\frac{1}{P_{R}}\left(\frac{\delta P_{r}}{\delta T_{r}}\right)_{S V}+\frac{\gamma}{\gamma-1} \frac{1}{T_{r}}\right]_{S V, T_{r}=0.7}
\end{aligned}
$$

For fluids with simple molecular structures, the negative term dominates the positive term because of the seemingly high heat capacity ratio, and the saturated vapour curve is negative and the fluid is wet. In the case of fluids with increased molecular complexity, the heat capacity ratio tends to decrease towards one, which produces a positive saturated vapour curve and dry fluid. In general, the critical temperature and acentric factor increases, while critical pressure decreases with molecular complexity [32]. 


\section{Practical limitations of working fluids}

\section{Evaporation and condensing pressure}

The cycle efficiency of an ORC is directly influenced by the higher and lower pressure limits of the system. Therefore, the higher the cycle pressure ratio the higher the thermal efficiency. However, the values of these pressure limits are constraint by practical restrictions [39]. For example, higher condensing pressure than the atmospheric pressure is required to avoid cool air leakage into the system which will result in lower cycle efficiency [24]. According to Lai et al. [7], the maximum pressure of the working fluid or the vapour pressure at which maximum temperature is achieved is 20 bar. This value was prescribed as a legal limit in many European countries and is in line with the value of maximum pressure of working fluids referred to in previous literature $[6,4,9]$. It is also important to consider these limits to avoid the presence of liquid droplets in the turbine after expansion. It has been observed that it is possible for both isentropic and dry fluids to form liquid during turbine expansion in all subcritical, superheated, and supercritical ORC [40]. Therefore, It is essential to have a steep enough slope of the saturated vapour curve on the T-s diagram, so that during expansion the working fluid cross the liquid-vapour phase and end up at the superheated vapour state as shown in Figure 3 [24].
One method for determining the cycle maximum pressure and temperature limits was proposed by Rayegan et al. [39]. He opined that near the critical pressure, small changes in temperature results in large changes in pressure which leads to cycle instability. Therefore, a reasonable distance between cycle maximum pressure and the working fluid critical point should be considered.

\section{Working fluid thermal stability}

The organic working fluid is chemically unstable at high temperature as it gets closer to their flame temperature, however, they are limited to about $600 \mathrm{~K}$ [11].

\section{Safety and environmental limitation}

The American Society of Heating, Refrigerating and Air-Conditioning Engineers (ASHRAE) standard 34 provides safety designation and classification for refrigerants. Toxicity and flammability are used to group refrigerant into six separate categories: A1 - non-flammable and nontoxic, A2 - lower flammability and non-toxic, A3 - non-toxic but flammable, B1 - non-flammable but toxic, B2 - toxic with lower flammability, and B3 - toxic and flammable (Table 1). The environmental considerations of the working fluid include the ozone depletion potential (ODP), global warming potential (GWP) and the atmospheric lifetime (ALT) [24]. Some fluids (R11, R12,

Table 1. Various working fluids with their physical and environmental properties

\begin{tabular}{|c|c|c|c|c|c|c|c|c|c|}
\hline \multirow{3}{*}{ Refrigerant } & \multirow{3}{*}{$\begin{array}{c}\begin{array}{c}\text { Molecular } \\
\text { Mass }\end{array} \\
(\mathrm{kg} / \mathrm{kmol})\end{array}$} & \multirow{3}{*}{$\begin{array}{l}{ }^{\mathrm{a}} T_{\text {crit }} \\
\left({ }^{\circ} \mathrm{C}\right)\end{array}$} & \multirow{3}{*}{$\begin{array}{l}{ }^{\mathrm{b}} P_{\text {crit }} \\
\text { (MPa) }\end{array}$} & \multirow{3}{*}{$\begin{array}{l}{ }^{c} T_{b p} \\
\left({ }^{\circ} \mathrm{C}\right)\end{array}$} & \multirow{3}{*}{ Fluid Type } & \multicolumn{4}{|c|}{ Environmental, Safety and health impact } \\
\hline & & & & & & \multicolumn{3}{|c|}{ Environmental data } & \multirow{2}{*}{$\begin{array}{l}\text { Safety data } \\
\text { ASHRAE } 24 \\
\text { safety group }\end{array}$} \\
\hline & & & & & & ${ }^{\mathrm{d} O D P}$ & \begin{tabular}{|c|}
$\begin{array}{c}{ }^{\circ} \mathrm{GWP} \\
(100 \mathrm{yr})\end{array}$ \\
\end{tabular} & $\begin{array}{l}\text { Atmospheric } \\
\text { life time }(\mathrm{yr})\end{array}$ & \\
\hline R134a & 102 & 101 & 4.059 & -26.09 & Dry & 0 & 1,300 & 13 & $\mathrm{~A} 1$ \\
\hline R227ea & 170 & 101.8 & 2.925 & -16.28 & wet & 0 & 3,220 & 34.2 & $\mathrm{~A} 1$ \\
\hline R1243zf & 96.05 & 103.8 & 3.518 & -25.43 & Wet & 0 & $<1$ & 7.0 days & A2 \\
\hline R152a & 66.05 & 113.3 & 4.520 & -24.05 & Dry & 0 & 138 & 1.4 & $\mathrm{~A} 2$ \\
\hline R236fa & 152 & 124.9 & 3.200 & -1.492 & Dry & 0 & 8,060 & 240 & $\mathrm{~A} 1$ \\
\hline R600a & 58.12 & 134.7 & 3.640 & -11.68 & Dry & 0 & 3 & $12 \pm 3$ & A3 \\
\hline R236ea & 152 & 139.3 & 3.429 & 6.105 & Dry & 0 & 1,330 & 10.7 & - \\
\hline R1234ze(Z) & 114 & 150.1 & 3.531 & 9.721 & Wet & 0 & 6 & - & $\mathrm{A} 2$ \\
\hline $\mathrm{R} 600$ & 58.12 & 152 & 3.796 & -0.5273 & Dry & 0 & 4 & $12 \pm 3$ & A3 \\
\hline R245fa & 134 & 154 & 3.651 & 15.18 & Dry & 0 & 858 & 7.6 & $\mathrm{~B} 1$ \\
\hline R1224yd(Z) & 148.5 & 155.5 & 3.337 & 14.61 & Wet & 0.88 & 0.00023 & 20 days & $\mathrm{A} 1$ \\
\hline HFE7000 & 200.1 & 164.6 & 2.478 & 34.17 & Dry & 0 & 530 & 4.9 & $\mathrm{~A} 1$ \\
\hline R1233zd(E) & 130.5 & 165.6 & 3.573 & 18.32 & Isentropic & 0 & 1 & $<0$ & $\mathrm{~A} 1$ \\
\hline R365mfc & 148.1 & 186.9 & 3.266 & 40.18 & Dry & 0 & 804 & 8.6 & $\mathrm{~A} 2$ \\
\hline R601a & 72.15 & 187.2 & 3.370 & 27.85 & Wet & 0 & $4 \pm 2$ & $12 \pm 3$ & A3 \\
\hline
\end{tabular}

a: Critical temperature; ${ }^{b}$ : Critical pressure; ${ }^{c}$ : Normal boiling point; ${ }^{\mathrm{d} O D P}$ : Ozone. 
R113, R114 and R115) have been phased out, and other HCFC fluids (R21, R22, R123, R124, $\mathrm{R} 141 \mathrm{~b}$ and R142b) are being phased out in 2020, therefore will not be used in this analysis.

\section{SYSTEM DESCRIPTION}

\section{Thermodynamic model of ORC}

This section discusses the processes involved in the simple and recuperated ORC configurations used in this analysis to perform working fluid selection evaluation. In this study, a hot stream of supercritical carbon dioxide $\left(\mathrm{S}-\mathrm{CO}_{2}\right)$ produced from GT-driven combined $\mathrm{R}-\mathrm{SCO}_{2}$ cycle is used as the heat source in both configurations to transfer heat to the ORC working fluid in the evaporator. In each case, subcritical, superheated, and supercritical operating conditions are applied (see Fig. 3a and $b$ ). The input parameters and assumptions made are presented in Table 2. All properties data were obtained from the engineering equation solver (EES) in-build database.

\section{Simple, and Recuperated ORC systems.}

Figure 2 shows the system configuration for simple and recuperated ORCs and their corresponding T-s diagrams presented in Figure 3. In the simple ORC system, the working fluid is pressurized to evaporator pressure by the pump (process $1-2$ ), it is preheated, evaporated, and/ or superheated in the heat exchanger (process $2-$ 3 ), the exit stream is then expanded in the turbine to produce power (process $3-4$ ), and eventually condensed (process $4-5$ ). In the recuperated ORC system, a regenerative heat exchanger is incorporated to utilize the energy in the turbine exit stream to pre-heat the pressurized liquid exiting the pump before entering the evaporator. This enable reduced condenser cooling load and higher evaporator exit temperature, consequently leading to higher cycle efficiency.

\section{Subcritical, superheated, and supercritical operating conditions.}

During operation of ORC at subcritical condition, the evaporator outlet temperature is below the critical point, and the working fluid is the saturated vapour as shown in Figure 3a(i). The saturated vapour at turbine entry is retained as saturated vapour and even terns towards dry vapour after turbine expansion, especially for dry and isentropic fluids. The maximum evaporator outlet temperature is limited by the working fluid critical temperature, usually sufficiently below the critical point. The evaporator pinch point temperature, alongside known values of temperature and mass flow rate of heat source, is used as a constraint to determine the mass flow rate of working fluid, thermal efficiency and net power output. In the case of superheated (Fig. 3a(ii) and $3 \mathrm{~b}$ (ii)) ORC, the evaporator outlet temperature is below the critical point, like the subcritical system, but the working fluid is superheated vapour and remains superheated after turbine expansion. Generally, the vapour is about $10{ }^{\circ} \mathrm{C}$ superheated above the evaporation temperature, and it's negatively related to the working fluid mass flow rate.

Finally, in supercritical ORC the pressure of the working fluid entering the evaporator is above the critical point, thus the working fluid does not undergo phase change in the heat transfer process, as illustrated by the T-s diagram in Figure 3a(iii). Supercritical ORC systems produce more power output and thermal performance because of the higher operating temperature, however, the high system pressure requires high pressure bearing equipment which significantly affects system costs.

\section{Thermodynamic analysis.}

In Table 3, the energy equation and exergy destruction relations for an individual component of the simple ORC and regenerative ORC are presented. These relations are used to calculate each process in the cycle as discussed previously.

Table 2. ORC design input parameters

\begin{tabular}{|l|l|c|}
\hline \multicolumn{1}{|c|}{ Parameters } & \multicolumn{1}{c|}{ Unit } & Value \\
\hline Heat source Temperature & $\mathrm{T}_{\text {HSource }}\left({ }^{\circ} \mathrm{C}\right)$ & 200 \\
\hline Heat source Pressure & $\mathrm{P}_{\mathrm{HS}}(\mathrm{MPa})$ & 15 \\
\hline ORC Turbine Inlet Pressure & $\mathrm{P}_{\text {turb }}(\mathrm{MPa})$ & 3 \\
\hline$\Delta \mathrm{T}$ pinch evaporator & $\Delta \mathrm{T}_{\text {evap }}\left({ }^{\circ} \mathrm{C}\right)$ & 10 \\
\hline$\Delta \mathrm{T}$ pinch condenser & $\Delta \mathrm{T}_{\text {cond }}\left({ }^{\circ} \mathrm{C}\right)$ & 5 \\
\hline$\Delta \mathrm{T}$ pinch recuperator & $\Delta \mathrm{T}_{\text {recup }}\left({ }^{\circ} \mathrm{C}\right)$ & 20 \\
\hline Heat sink temperature & $\mathrm{T}_{\text {HSink }}\left({ }^{\circ} \mathrm{C}\right)$ & 20 \\
\hline Heat sink pressure & $\mathrm{P}_{\text {sink }}(\mathrm{kPa})$ & 50 \\
\hline Isentropic turbine efficiency & $\eta_{\text {turb }}[\%]$ & 85 \\
\hline Isentropic pump efficiency & $\eta_{\text {pump }}[\%]$ & 85 \\
\hline Evaporator effectiveness & $\varepsilon_{\text {turb }}[\%]$ & 65 \\
\hline Condenser effectiveness & $\varepsilon_{\text {pump }}[\%]$ & 65 \\
\hline Recuperator effectiveness & $\varepsilon_{\text {recup }}[\%]$ & 65 \\
\hline
\end{tabular}




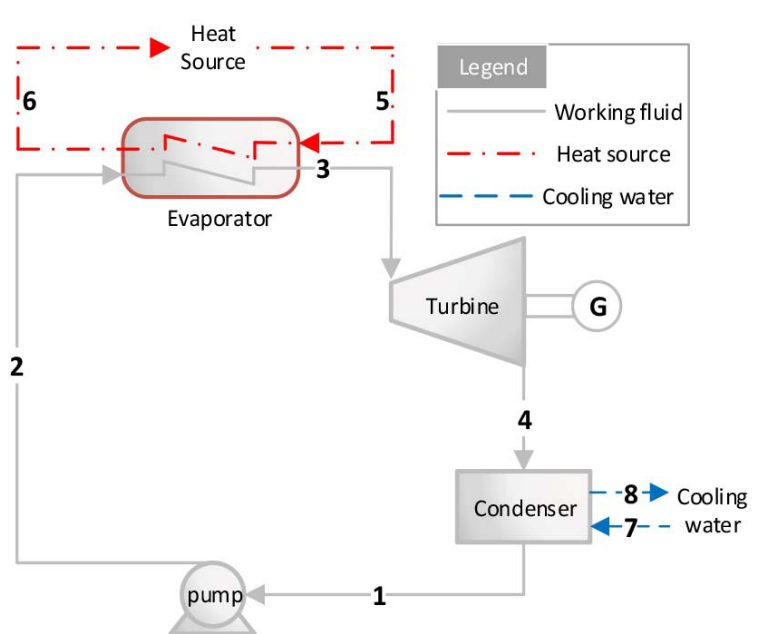

Fig. 2a. System diagram of simple ORC

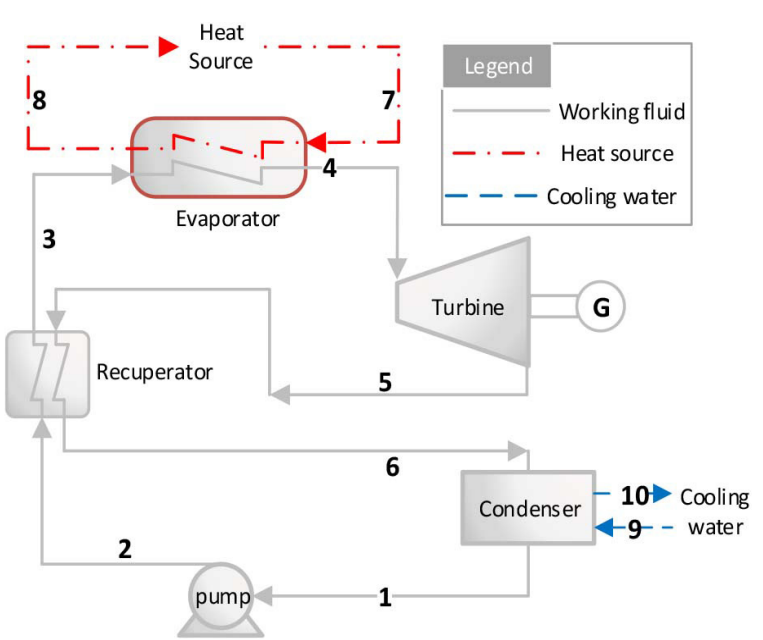

Fig. 2b. System diagram of recuperative ORC
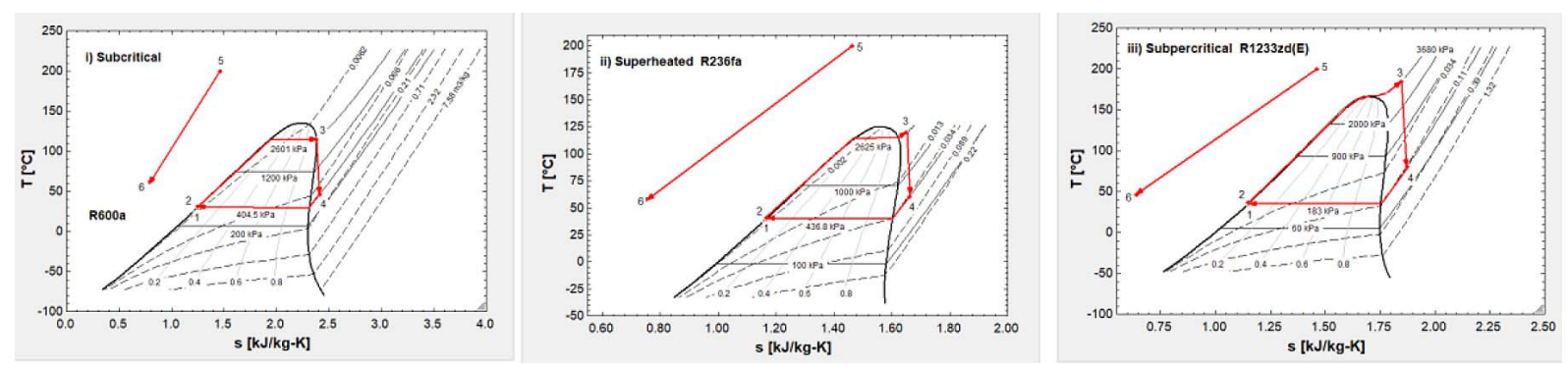

Fig. 3a. T-s diagram for simple ORC under three operation conditions; (i) Subcritical (Left); (ii) Superheated (Middle); (iii) Supercritical (Right)
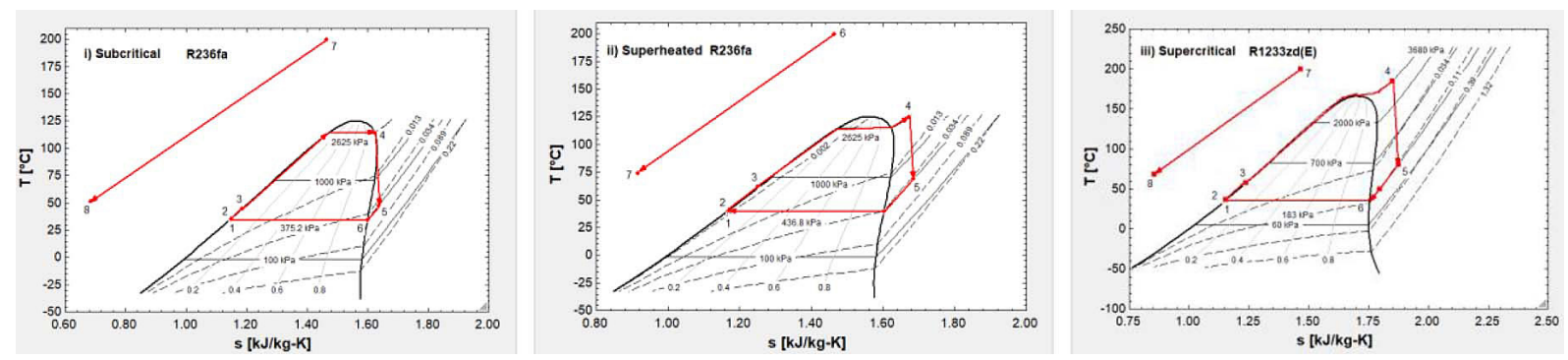

Fig. 3b. T-s diagram for recuperative ORC under three operation conditions; (i) Subcritical (Left); (ii) Superheated (Middle); (iii) Supercritical (Right)

Thermal efficiency is defined as the ratio of the net power produced to the energy input to the system.

$$
\begin{gathered}
\eta_{\text {thermal }}=\frac{\dot{\mathrm{W}}_{\text {net }}}{\dot{\mathrm{Q}}_{\text {Evap }}} \\
\dot{\mathrm{W}}_{\text {net }}=\dot{\mathrm{W}}_{\text {Turb }}-\dot{\mathrm{W}}_{\text {pump }}
\end{gathered}
$$

\section{Exergy Analyses.}

Exergy is the maximum theoretical work that can be derived from a system as it interacts with the surrounding. It indicates a measure of the departure of a state of a system from the surrounding in equilibrium condition. The steady-state of exergy balance of a control volume is defined as:

$$
\sum_{j}\left(1-\frac{T_{o}}{T_{j}}\right) \dot{Q}_{j}-\dot{W}_{c . v}+\sum_{i} \dot{m}_{i} E x_{i}-\sum_{j} \dot{m}_{e} E x_{e}-\dot{E} x_{d}=0
$$

where: $E x_{i}$ is exergy per unit mass, and $\dot{E} x_{d}$ is the exergy destruction rate; the subscript $a$, $i, e$ refers to the surroundings, inlet, and exit respectively.

The physical exergy per unit mass flow rate is defined as [41]:

$$
E x^{p h}=\left(h-h_{o}\right)-T_{o}\left(s-s_{o}\right)
$$


Table 3. Energy equation and exergy destruction relations for individual components of the cycles

\begin{tabular}{|c|c|c|c|}
\hline Cycle & Component & Energy Equations & Exergy Destruction Relations \\
\hline \multirow{4}{*}{ Simple cycle } & Evaporator & $\begin{array}{l}\dot{\mathrm{m}}_{\text {sco }}\left(\mathrm{h}_{5}-\mathrm{h}_{6}\right)=\dot{\mathrm{m}}_{\mathrm{wf}}\left(\mathrm{h}_{3}-\mathrm{h}_{2}\right) \\
\dot{\mathrm{Q}}_{\text {Evap }}=\dot{\mathrm{m}}_{\mathrm{wf}}\left(\mathrm{h}_{3}-\mathrm{h}_{2}\right)\end{array}$ & $\dot{E} x_{D_{\text {Evap }}}=\left(\dot{E x_{5}}+\dot{E x_{2}}\right)-\left(\dot{E x_{3}}+\dot{E x_{6}}\right)$ \\
\hline & Turbine & $\begin{array}{l}\eta_{\text {Turb }}=\frac{w_{A}}{w_{s}}=\frac{h_{3}-h_{4}}{h_{3}-h_{4 s}} \\
W_{\text {Turb }}=\dot{m}_{w f}\left(h_{3}-h_{4}\right)\end{array}$ & $\dot{\mathrm{E}} \mathrm{D}_{\mathrm{D}_{\text {Turb }}}=\dot{\mathrm{Ex}} \mathrm{x}_{3}-\left(\dot{\mathrm{E} \mathrm{x}_{4}}+\mathrm{W}_{\text {Turb }}\right)$ \\
\hline & Condenser & $\begin{array}{l}\dot{\mathrm{m}}_{\mathrm{cw}}\left(\mathrm{h}_{8}-\mathrm{h}_{7}\right)=\dot{\mathrm{m}}_{\mathrm{wf}}\left(\mathrm{h}_{4}-\mathrm{h}_{1}\right) \\
\dot{\mathrm{Q}}_{\mathrm{Econ}}=\dot{\mathrm{m}}_{\mathrm{wf}}\left(\mathrm{h}_{4}-\mathrm{h}_{1}\right)\end{array}$ & $\dot{E x_{D_{\text {Con }}}}=\left(\dot{E x_{4}}+\dot{E x_{7}}\right)-\left(\dot{E x_{1}}+\dot{E x_{8}}\right)$ \\
\hline & Pump & $\begin{array}{l}\eta_{\text {Pump }}=\frac{w_{s}}{w_{A}}=\frac{h_{2 s}-h_{1}}{h_{2}-h_{1}} \\
W_{\text {Pump }}=\dot{m}_{w f}\left(h_{2}-h_{1}\right)\end{array}$ & $\dot{E x}_{\text {DPump }_{\text {Pump }}}=\left(\dot{E x_{1}}+W_{\text {pump }}\right)-\dot{E x_{2}}$ \\
\hline \multirow{5}{*}{ Simple ORC with $\mathrm{HX}$} & Evaporator & $\begin{array}{c}\dot{\mathrm{m}}_{\mathrm{sco}}\left(\mathrm{h}_{7}-\mathrm{h}_{8}\right)=\dot{\mathrm{m}}_{\mathrm{wf}}\left(\mathrm{h}_{4}-\mathrm{h}_{3}\right) \\
\dot{\mathrm{Q}}_{\text {Evap }}=\dot{\mathrm{m}}_{\mathrm{wf}}\left(\mathrm{h}_{4}-\mathrm{h}_{3}\right)\end{array}$ & $\dot{E x_{D_{E v a p}}}=\left(\dot{E x_{7}}+\dot{E x_{3}}\right)-\left(\dot{E x_{4}}+\dot{E x_{8}}\right)$ \\
\hline & Turbine & $\begin{array}{l}\eta_{\text {Turb }}=\frac{w_{A}}{w_{s}}=\frac{h_{4}-h_{5}}{h_{4}-h_{5 s}} \\
W_{\text {Turb }}=\dot{m}_{w f}\left(h_{4}-h_{5}\right)\end{array}$ & $\dot{E x_{D_{\text {Turb }}}}=\dot{E x_{4}}-\left(\dot{E x_{5}}+W_{\text {Turb }}\right)$ \\
\hline & Condenser & $\begin{array}{l}\dot{\mathrm{m}}_{\mathrm{cw}}\left(\mathrm{h}_{10}-\mathrm{h}_{9}\right)=\dot{\mathrm{m}}_{\mathrm{wf}}\left(\mathrm{h}_{6}-\mathrm{h}_{1}\right) \\
\dot{\mathrm{Q}}_{\mathrm{Econ}}=\dot{\mathrm{m}}_{\mathrm{wf}}\left(\mathrm{h}_{6}-\mathrm{h}_{1}\right)\end{array}$ & $\dot{E} x_{D_{\text {Con }}}=\left(\dot{E} x_{6}+\dot{E} x_{9}\right)-\left(\dot{E x_{1}}+\dot{E} x_{10}\right.$ \\
\hline & Regenerator & $\begin{array}{l}\dot{\mathrm{m}}_{2}\left(\mathrm{~h}_{3}-\mathrm{h}_{2}\right)=\dot{\mathrm{m}}_{5}\left(\mathrm{~h}_{5}-\mathrm{h}_{6}\right) \\
\dot{\mathrm{Q}}_{\mathrm{Reg}}=\dot{\mathrm{m}}_{2}\left(\mathrm{~h}_{3}-\mathrm{h}_{2}\right)\end{array}$ & $\dot{E x_{D_{R e c}}}=\left(\dot{E x_{2}}+\dot{E x_{5}}\right)-\left(\dot{E x_{3}}+\dot{E x_{6}}\right)$ \\
\hline & Pump & $\begin{array}{l}\eta_{\text {Pump }}=\frac{w_{s}}{w_{A}}=\frac{h_{2 s}-h_{1}}{h_{2}-h_{1}} \\
W_{\text {Pump }}=\dot{m}_{w f}\left(h_{2}-h_{1}\right)\end{array}$ & $\dot{E x}_{\text {DPump }_{\text {Pump }}}=\left(\dot{E x_{1}}+W_{\text {pump }}\right)-\dot{E x_{2}}$ \\
\hline
\end{tabular}

where: $h$ and $s$ are the specific enthalpies and specific entropy respectively.

The inlet exergy of the simple ORC system is expressed as follows:

$$
\mathrm{Ex}_{\mathrm{in}}=\dot{m}_{\mathrm{sco}}\left(\mathrm{Ex}_{5}-\mathrm{Ex}_{6}\right)
$$

The exergy efficiency of the ORC systems is defined as:

$$
\eta_{\text {exergy }}=\frac{W_{\text {net }}}{E x_{\text {in }}}
$$

The overall electrical exergy efficiency of the system, which is the ratio of net electrical output to the exergy input, is given as:

$$
\eta_{\text {ex,elec }}=\frac{\text { Ex }_{\mathrm{d}_{\text {Total }}}}{\text { Ex }_{\text {in }}}
$$

Where the total exergy destruction, $\mathrm{Ex}_{\mathrm{d}_{\text {Total }}}$ is defined as:

$$
\begin{aligned}
& E_{\mathrm{d}_{\text {Total }}}=\mathrm{Ex}_{\mathrm{d}_{\text {Evap }}}+\mathrm{Ex}_{\mathrm{d}_{\mathrm{Turb}}}+ \\
& +\mathrm{Ex}_{\mathrm{d}_{\text {Reg }}}+\mathrm{Ex}_{\mathrm{d}_{\text {Cond }}}+\mathrm{Ex}_{\mathrm{d}_{\text {pump }}}
\end{aligned}
$$

The exergy destruction equations for the system components based on [42, 43] is shown in Table 3. The fuel depletion ratio, which is an exegetic parameter for system performance improvement is defined as:

$$
\mathrm{Y}_{\mathrm{D}_{\mathrm{J}}}=\frac{E \mathrm{Ex}_{\mathrm{D}_{\mathrm{J}}}}{E \mathrm{Ex}_{\mathrm{in}}}
$$

Irreversibility ratio is the ratio of exergy destruction in the $J$ component to the total exergy destruction rate in the system.

$$
\bar{Y}_{D_{J}}=\frac{E x_{D_{J}}}{E x_{d_{\text {Total }}}}
$$

Another important parameter for system performance improvement is the Improvement potential (IMP), which indicates how much additional improvement is possible within a component or system.

$$
\mathrm{IMP}_{\mathrm{J}}=\left(1-\frac{\eta_{\text {ex,elec }}}{100}\right) \mathrm{Ex}_{\mathrm{D}_{\mathrm{J}}}
$$

\section{Component sizing}

The size of the turbine expander and heat exchanger used for the ORC system has a significant impact on the performance and cost of the system. The performance of turbines with different working fluids can be compared using two important parameters: the SP and VFR [44].

The SP is defined as:

$$
S P=\frac{\sqrt{V_{\text {out }}}}{\sqrt[4]{\Delta h_{\text {is }}}}
$$

and, VFR defined as:

$$
V F R=\frac{\mathrm{v}_{\text {out }}}{\mathrm{V}_{\text {in }}}
$$

where: $V_{\text {out }}$ and $V_{\text {in }}$ are the volumetric flow rates at turbine outlet and inlet, is the enthalpy change along with the turbine isentropic expansion.

The SP indicates the relative size of the turbine expander. A large SP indicates a larger expander 
diameter, which implies higher costs. The VFR index indicates the turbine stages required, smaller VFR value means fewer turbine stages are required resulting in higher isentropic efficiency. The VFR for a single stage is less than 9 and high isentropic efficiency are generally obtained from VFR less than 100. The ORC is also affected by the size and cost of the heat exchangers, which can be estimated using UA (i.e., a product of the heat transfer coefficient, $U$, and the heat transfer area, A). A higher UA value means that the heat exchanger size is large and also expensive.

$$
\mathrm{UA}=\frac{\mathrm{Q}}{\Delta \mathrm{T}_{\mathrm{lm}}}
$$

$\Delta T_{l m}$ for a countercurrent heat exchanger is defined as:

$$
\Delta \mathrm{T}_{\mathrm{lm}}=\frac{\Delta \mathrm{T}_{1}-\Delta \mathrm{T}_{2}}{\ln \left(\frac{\Delta \mathrm{T}_{1}}{\Delta \mathrm{T}_{2}}\right)}
$$

where: $Q$ is the heat transfer, $\Delta T_{l m}$ is the logarithmic mean temperature difference, $\Delta T_{1}$ is the maximum temperature difference at both ends of the heat exchanger, and $\Delta T_{2}$ is the minimum temperature difference at both ends of the heat exchanger.

\section{RESULTS AND DISCUSSION}

\section{Performance analyses of simple ORC}

15 different organic working fluids with critical temperatures in the range of $124-187^{\circ} \mathrm{C}$ (see Table 1) are simulated in a simple ORC under subcritical, superheated and supercritical conditions. The performance of the working fluids are evaluated in terms of net power output, thermal efficiency, maximum cycle pressure and total heat transfer capacity, $\mathrm{UA}_{\text {evap }}$, as well as SP and VFR. The cycle is flexibly designed to ensure twophase fluid during turbine expansion is avoided, therefore, selecting the evaporation temperature below the critical temperature for each working fluid in both the subcritical and superheated operating conditions. For the supercritical ORC, an evaporation temperature higher than the critical temperature for each working fluid is selected to avoid condensation at the turbine exit. A Superheating of $5{ }^{\circ} \mathrm{C}$ is applied to the superheated cycle and a high cycle pressure of $P_{S C}=1.03 \cdot P_{C r i t}$, used for the supercritical cycle. As mentioned previously, the ORC is driven by hot streams of $\mathrm{S}-\mathrm{CO}_{2}$ with a constant heat temperature of $200{ }^{\circ} \mathrm{C}$ and mass flow rate of $80 \mathrm{~kg} / \mathrm{s}$.
The net power output, thermal efficiency, maximum pressure, heat transfer capacity ( $\left.\mathrm{UA}_{\text {evap }}\right), \mathrm{SP}$ and VFR are chosen as the parameters used within this study for comparing the performance characteristics of the different working fluids. However, since the primary objective of the ORC is to produce maximum power output, which reflects the capacity of heat recovery from the heat source [45], the maximum net power output, highest operating pressure, $\mathrm{UA}_{\text {evap }}$ and SP was used as screening criteria for selecting suitable working fluid for subcritical ORC.

Figure 4a represents the net power output and corresponding evaporation temperature $\left(T_{\text {evaa }}\right)$ between $90{ }^{\circ} \mathrm{C}$ and values just below the critical temperature of the working fluid. The value of the maximum net power output of different working fluids vary with their corresponding $T_{\text {evap }}$. Figure $4 \mathrm{a}$ indicate that among all the different fluids investigated, R600a, R245fa, R236fa, R236ea and HFE7000 produced the highest net power output of 3.98 MW, 3.348 MW, 3.344 MW, 3.344 MW and $3.223 \mathrm{MW}$, respectively.

Figure $4 \mathrm{~b}$ show an illustrative comparison between thermal efficiency and net power output of the different working. The box plot provides statistical information, such as mean, median, outliers (maximum values), and $25-75 \%$ percentile, for the $T_{\text {evap }}$ range discussed previously. R600a, R245fa and R236fa are observed to have the highest values of net power output, and R365mfc and R601a associated with the lowest values. It can be deduced that working fluids with lower critical temperature produced higher net power output, while those with higher critical temperature terns to have low net power output for subcritical simple ORC. The reverse trend is observed for thermal efficiency, which is understandable since thermal efficiency increases with temperature.

Figure $4 \mathrm{c}$ show the maximum cycle pressure and total heat capacity $\left(\mathrm{UA}_{\text {evap}}\right)$ of different working fluids for the $T_{\text {evap }}$ values under consideration. R245fa is observed to have the highest pressure of $3.381 \mathrm{MPa}$ at maximum net power output compared to other working fluids. In ORC, high operating pressure indicates an increased investment cost to meet the material and structural requirement of the high-pressure plant. At maximum power, the working pressures of $3.364 \mathrm{MPa}, 2.625 \mathrm{MPa}, 2.879 \mathrm{MPa}$ and $2.284 \mathrm{MPa}$ corresponding to R600a, R236fa, R236ea and HFE7000, respectively. Also, for 
the working fluids being investigated, R600a $(1487 \mathrm{~kW} / \mathrm{k}), \mathrm{R} 236 \mathrm{fa}(784.5 \mathrm{~kW} / \mathrm{k})$ and R236ea $(553.8 \mathrm{~kW} / \mathrm{k})$ have the highest value of $\mathrm{UA}_{\text {evap }}$, while R601a (79.4kW/k), R365mfc $(96.21 \mathrm{~kW} / \mathrm{k})$ and R1233zd(E) have the lowest value of $\mathrm{UA}_{\text {evap }}$. The value of $\mathrm{UA}_{\text {evap }}$ is important from the economic viewpoint, as higher values indicate increase cost associated with a large and expensive evaporator heat exchanger.

Figure $4 \mathrm{~d}$ demonstrate the expander SP and VFR for the different working fluids. R236fa $(0.101 \mathrm{~m})$, R236ea $(0.1145 \mathrm{~m})$ and R600a $(0.1171 \mathrm{~m})$ have SP values less than $0.12 \mathrm{~m}$, the R1234ze(Z) $(0.131 \mathrm{~m}), \mathrm{R} 1224 \mathrm{yd}(\mathrm{Z})(0.135$ $\mathrm{m}), \mathrm{R} 245 \mathrm{fa}(0.1365 \mathrm{~m})$ and R600 $(0.1381 \mathrm{~m})$ have $0.12 \mathrm{~m}<\mathrm{SP} \leq 0.14 \mathrm{~m}$, and then HFE7000 $(0.1778 \mathrm{~m}), \mathrm{R} 601 \mathrm{a}(0.207 \mathrm{~m})$ and R365mfc $(0.2111 \mathrm{~m})$ having $\mathrm{SP} \leq 0.16 \mathrm{~m}$. In Figure $4 \mathrm{~d}$, R600a (13.63), R236fa (12.38) and R236ea (18.04) are observed with the lowest values of

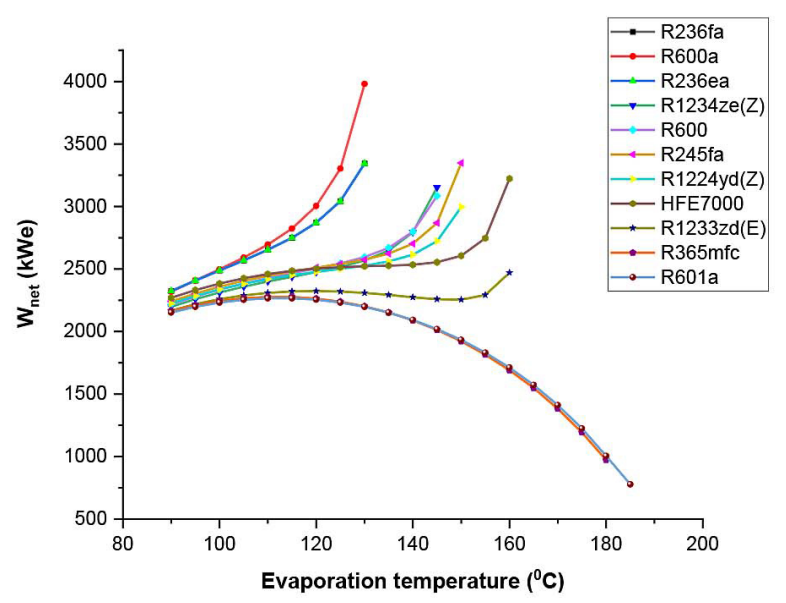

Fig. 4a. $\mathrm{W}_{\text {net }}$ and $\mathrm{T}_{\text {evap }}$ of different working fluids

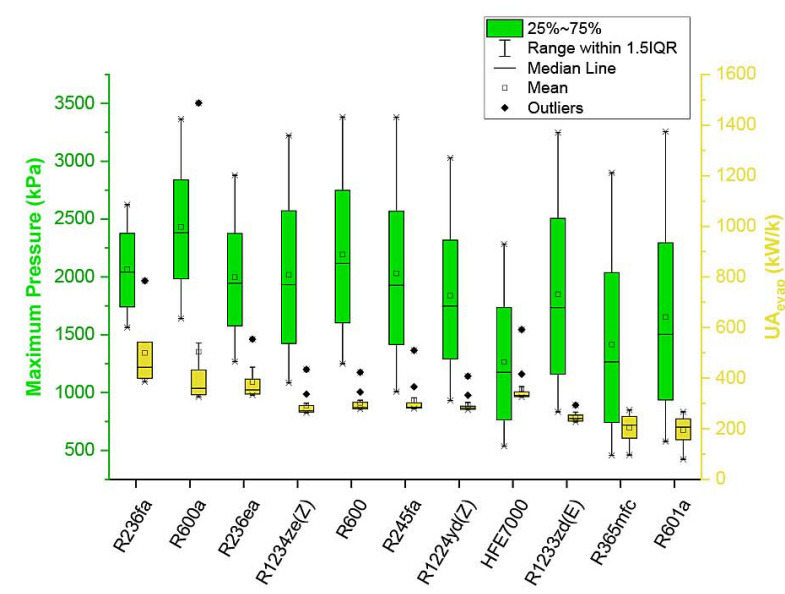

Fig. 4c. $\mathrm{P}_{\max }$ and $\mathrm{UA}_{\text {evap }}$ of various working fluids
VFR, while R365mfc (70.64) is associated with the highest values of the VFR. Both SP and VFR are important economic indices for ORC, as there indicate the expander diameter/size and the number of turbine stages required, respectively. Therefore, working fluids with a lower value of SP and VFR are desired.

Based on the technical and economic consideration discussed above, R600a, R236fa, R236ea and R245fa are considered suitable working fluids for subcritical ORC under the given conditions in this study.

Figure 5a-c illustrate the performance characteristics of different working fluids operating under superheated condition. 5-degree superheating has been adopted in this study. Results for the superheated simple ORC show a similar trend as the subcritical simple ORC, with R236fa, R600a, R236ea, R600, R1224yd(Z) and R245fa are considered suitable working fluids for superheated ORC.

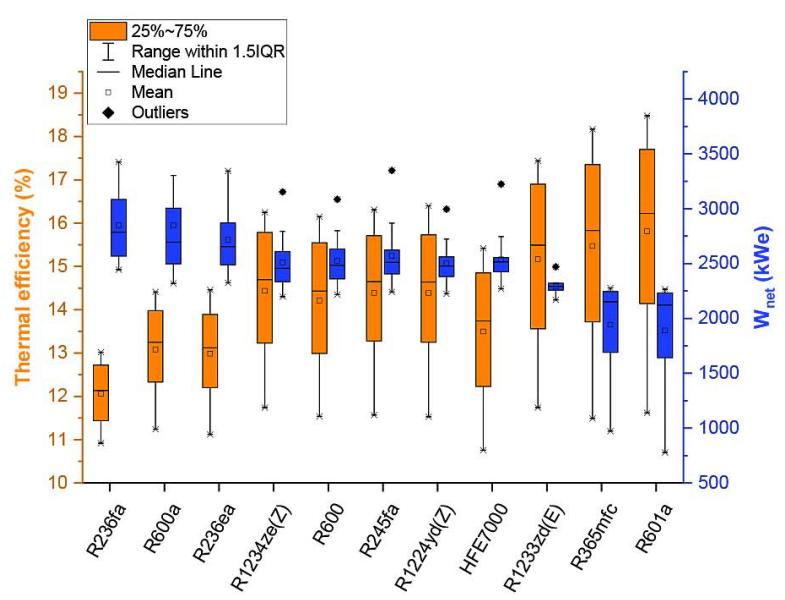

Fig. 4 b. $\eta_{\text {th }}$ and $W_{\text {net }}$ of different working fluids

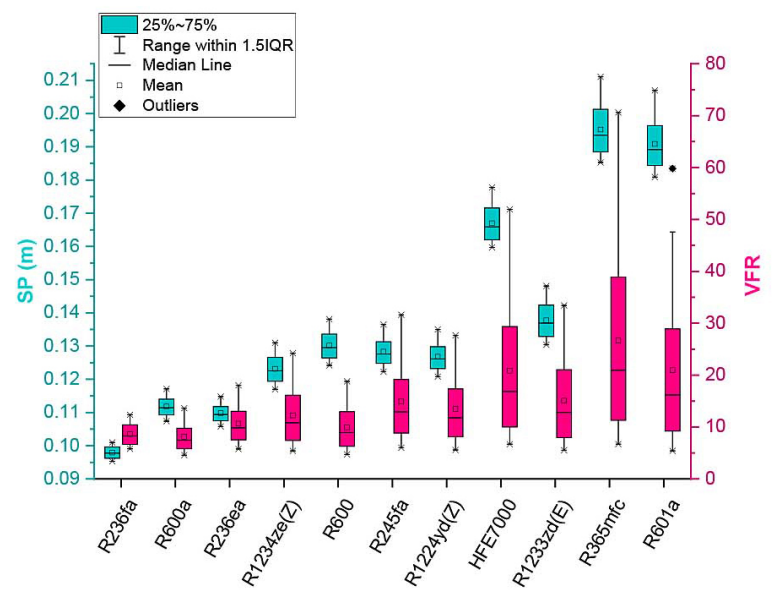

Fig. 4d. SP and VFR of various working fluids

Fig. 4. Net power output, thermal efficiency, maximum pressure, UA ${ }_{\text {evap }}$, SP and VFR of various working fluids for simple ORC under subcritical conditions 
In the supercritical simple ORC, to prevent fluid condensation at turbine exit, the values of $\mathrm{T}_{\text {evap }}$ are chosen such that there are higher than the fluid critical temperature but lower than heat source temperature. Figure 6a show the net power output corresponding to a range of $T_{\text {evap }}$ for the different working fluids being studied. The values of $\mathrm{W}_{\text {net }}$ for the range of $\mathrm{T}_{\text {evap }}$ considered in the different working fluids, are observed to be fairly constant, with higher values of associated with working fluids of high critical temperature and low $\mathrm{W}_{\text {net }}$ the value associated with fluids of lower critical temperature. That means, the closer the critical temperature of a fluid to the heat source temperature the higher the $\mathrm{W}_{\text {net }}$ produced.

In Figure 6b, the thermal efficiency and $\mathrm{W}_{\text {net }}$ of the supercritical simple ORC for different working fluids is presented. R1233zd(E) (4.433MW, 17.87\%), R1234ze(Z) (4.253MW,
$17.16 \%)$, R601a (4.173MW, 16.8\%) and R365mfc $(4.134 \mathrm{MW}, 16.58 \%)$ are working fluids with the highest net power output and thermal efficiency compared to other fluids. The high value of $W_{\text {net }}$ and $\eta_{\text {th }}$ in supercritical ORC has a strong relationship with the fluid's high critical temperature and molecular weight.

Figure $6 \mathrm{c}$ show cycle operating pressure and $\mathrm{UA}_{\text {evap }}$ of the different working fluids. HFE7000 is observed to have the highest value of $\mathrm{UA}_{\text {evap }}$ $(2024 \mathrm{~kW} / \mathrm{k})$, even though it has a relatively lower $P_{\text {max }}$ value compared to other fluids.

The SP and VFR characteristics of different working fluids under consideration is presented in Figure 6d. The values of SP and VFR increase with a fluid having a high critical temperature.

Based on performance and economic consideration of the different working fluids, R1233zd(E) and R1234ze(Z) are more suitable for supercritical ORC.

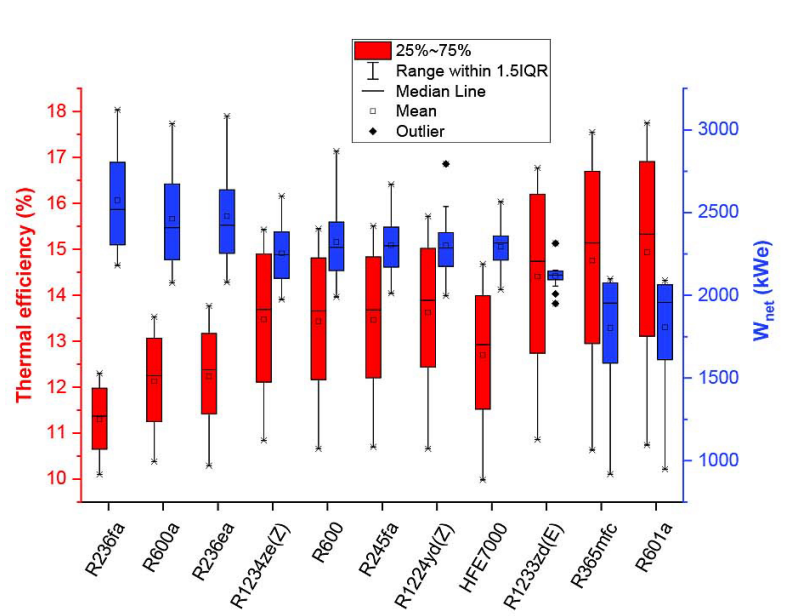

Fig. 5a. $\eta_{\text {th }}$ and $W_{\text {net }}$ of various working fluids

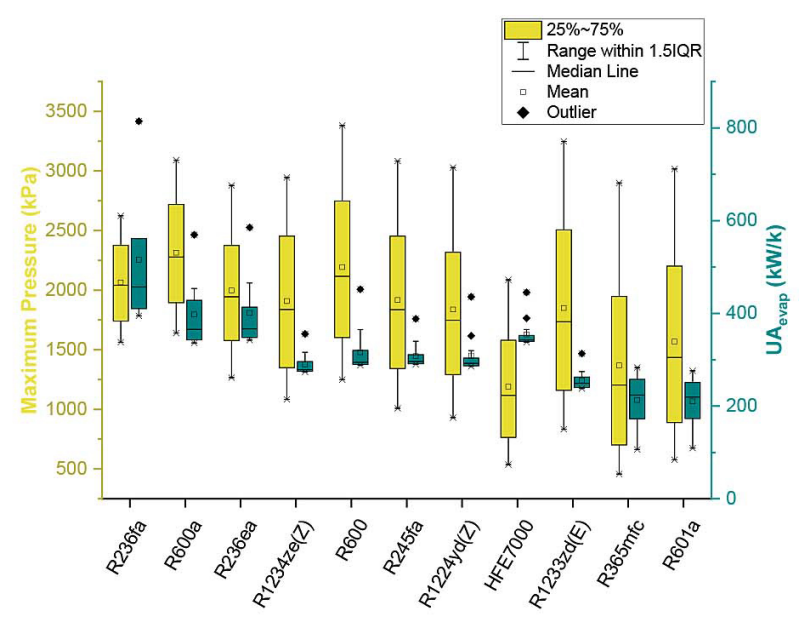

Fig. 5b. $\mathrm{P}_{\max }$ and $\mathrm{UA}_{\text {evap }}$ of various working fluids

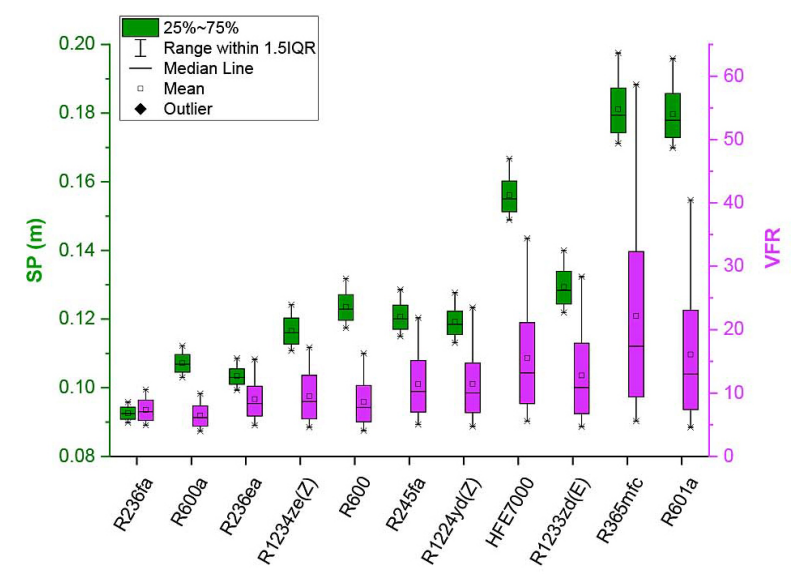

Fig. 5c. SP and VFR of various working fluids

Fig. 5. Net power output, thermal efficiency, maximum pressure, UA ${ }_{\text {evap }}$, SP and VFR of various working fluids for simple ORC under superheated conditions 


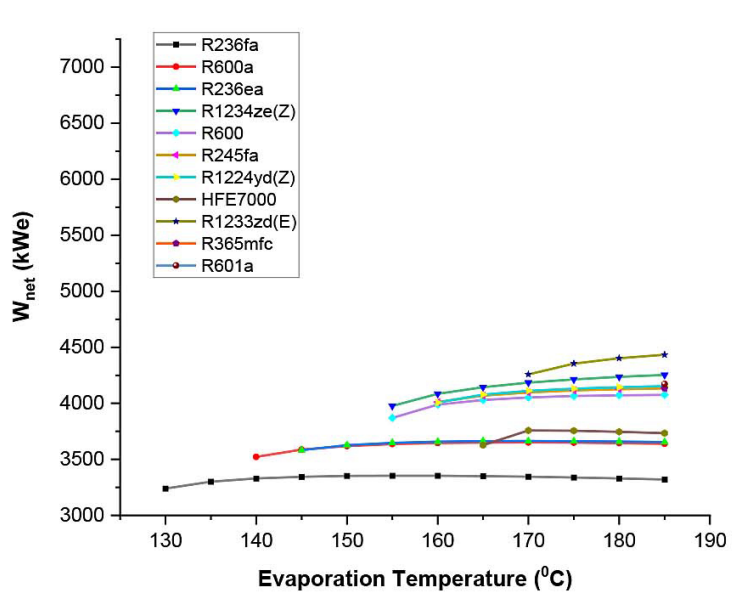

Fig. 6a. $\mathrm{W}_{\text {net }}$ and $\mathrm{T}_{\text {evap }}$ of different working fluids

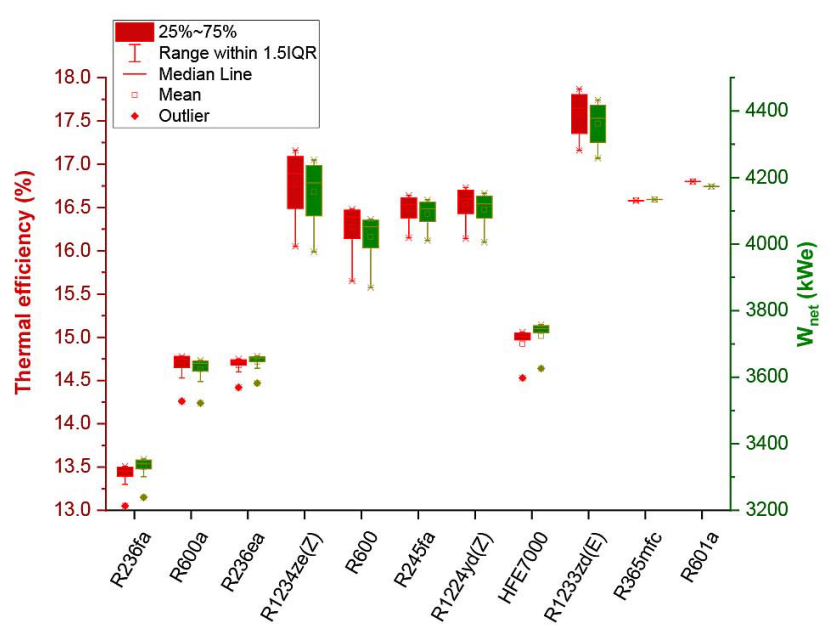

Fig. 6b. $\eta_{\text {th }}$ and $W_{\text {net }}$ of various working fluids

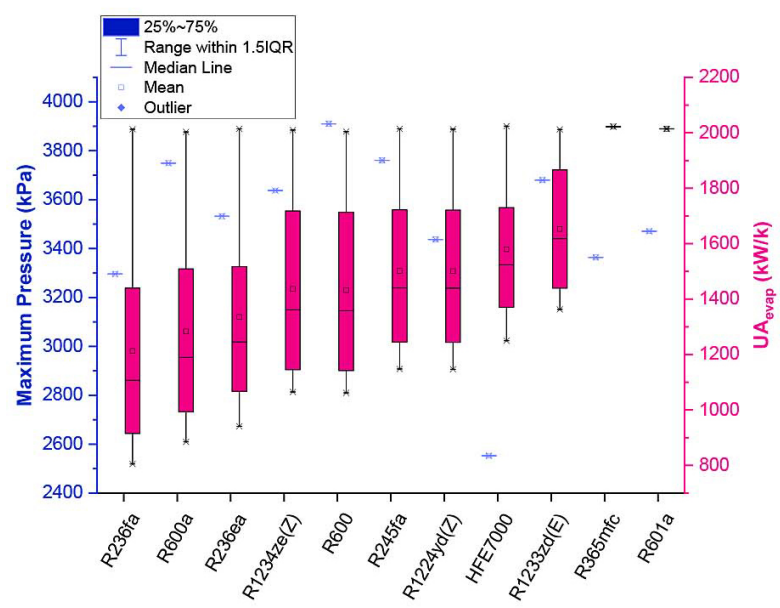

Fig. 6c. $\mathrm{P}_{\text {max }}$ and $\mathrm{UA}_{\text {evap }}$ of various working fluids

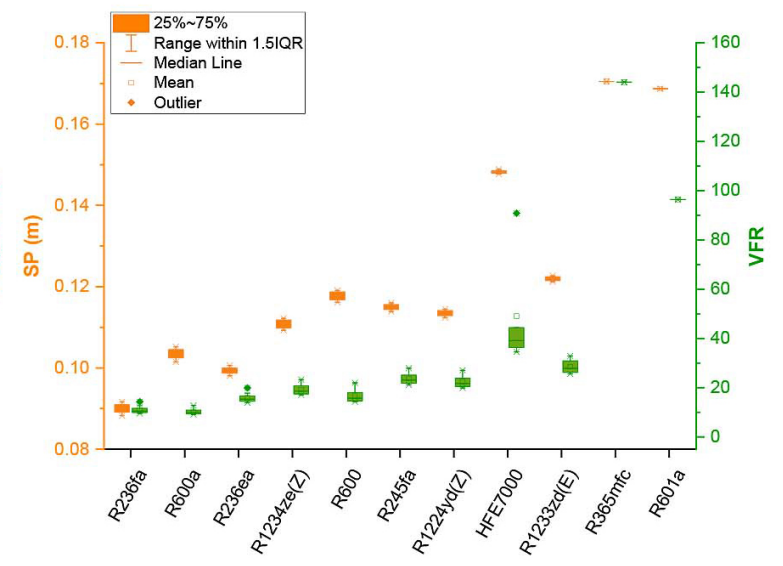

Fig. 6d. SP and VFR of various working fluids

Fig. 6. Net power output, thermal efficiency, maximum pressure, UA ${ }_{\text {evap }}$, SP and VFR of various working fluids for simple ORC under supercritical conditions

\section{Performance analyses of recuperative ORC}

The configuration and T-s diagrams of recuperative ORC illustrated in Figure $2 \mathrm{~b}$ and $3 \mathrm{~b}$ indicated that the major difference between simple and recuperative ORC is the additional heat exchanger incorporated to improve cycle efficiency by reclaiming excess heat from the turbine exit stream to preheat the working fluid before entering the evaporator. The performance analyses of recuperative ORC under subcritical, superheated and supercritical operating condition are simulated with the same input cycle parameter as the simple ORC discussed previously.

Figure $7 \mathrm{a}$ show the $\mathrm{W}_{\text {net }}$ and their corresponding values of $\mathrm{T}_{\text {evap }}$ for the different working fluid under consideration. It is observed that as $\mathrm{T}_{\text {evap }}$ increases, the $\mathrm{W}_{\text {net }}$ also increases with maximum $\mathrm{W}_{\text {net }}$ obtained at $\mathrm{T}_{\text {evap }}$ closest to the critical temperature of the fluid in subcritical recuperative ORC. However, R365mfc and R601a show a different trend, increasing at first and then descend afterwards. Figure 7 a show a similar trend with that in subcritical simple ORC, except that the values of $\mathrm{W}_{\text {net }}$ are lower in recuperative ORC.

Figure $7 \mathrm{~b}$ presents the thermal efficiency, $\eta_{\text {th }}$ and $W_{\text {net }}$ performance characteristics of each working fluid within $T_{\text {evap }}$ range of the working fluids as shown in Figure 7a.

It reveals that the working fluids R236fa (3.122MW), R245fa (3.120MW), R234ea (3.084MW) and HFE7000 (3.013MW) have the highest value of $\mathrm{W}_{\text {net }}$ compared to other fluids, and the lowest value of $\mathrm{W}_{\text {net }}$ associated with R601a (0.734 MW) and R365mfc (0.9184 MW). The trend shows a correlation between high $\mathrm{W}_{\text {net }}$ 
and fluids with low critical temperature or lower $\mathrm{T}_{\text {evap }}$. However, thermal efficiency shows the reverse trend, increasing as the fluid's critical temperature or $\mathrm{T}_{\text {evap }}$ increases. In comparison with the subcritical simple ORC, the subcritical recuperative ORC have higher thermal efficiencies at the price of lower $\mathrm{W}_{\text {net }}$. For example, R236fa at $\mathrm{T}_{\mathrm{e}}$ vap of $115{ }^{\circ} \mathrm{C}$ have a $1.138 \%$ increase in $\eta_{\text {th }}$ and $9.7 \%$ decrease on $\mathrm{W}_{\text {net }}$ compared to the subcritical simple ORC. Similarly, R601a at $\mathrm{T}_{\text {evap }}$ of $185{ }^{\circ} \mathrm{C}$ also achieved a $13.56 \%$ increase in $\eta_{\text {th }}$ with a corresponding $5.94 \%$ decrease in $\mathrm{W}_{\text {net }}$ compared to the simple ORC.

Figure $7 \mathrm{c}$ shows the maximum cycle pressure, $\mathrm{P}_{\max }$ and within the $\mathrm{T}_{\text {evap }}$ range (Fig. 7a) of each working fluid considered. $\mathrm{P}_{\max }$ is higher for fluids with higher critical temperature due to their capacity for high $\mathrm{T}_{\text {evap }}$. $\mathrm{UA}_{\text {evap }}$ is observed to have a correlation with $\mathrm{W}_{\text {net }}$, with HFE7000 $(801.5 \mathrm{~kW} / \mathrm{k}), \mathrm{R} 236 \mathrm{fa}(796.8 \mathrm{~kW} / \mathrm{k})$ and R236ea (593.6kW/k) having the highest values and R601a $(78.88 \mathrm{~kW} / \mathrm{k})$ associated with low value.

The SP and VFR for subcritical recuperative ORC is presented in Figure 7d. It shows a similar trend as the subcritical simple ORC (Fig. 4d), with the fluids R236fa $(0.0958 \mathrm{~m}, 12.38)$, R236ea $(0.1058 \mathrm{~m}, 18.04)$ and R600a $(0.1074 \mathrm{~m}, 13.63)$ having the lowest values of SP and VFR, respectively, which is desirable from the economic viewpoint.

Figure 8a show thermal efficiency, $\eta_{\text {th }}$ and $\mathrm{W}_{\text {net }}$ of the working fluids for superheated recuperative ORC. Again, indicates a similar trend with that of superheated simple ORC (Fig. 5a), with R236fa (3.122MW, 12.17\%) and R601a $(0.948 \mathrm{MW}, 21.6 \%)$ having maximum values of

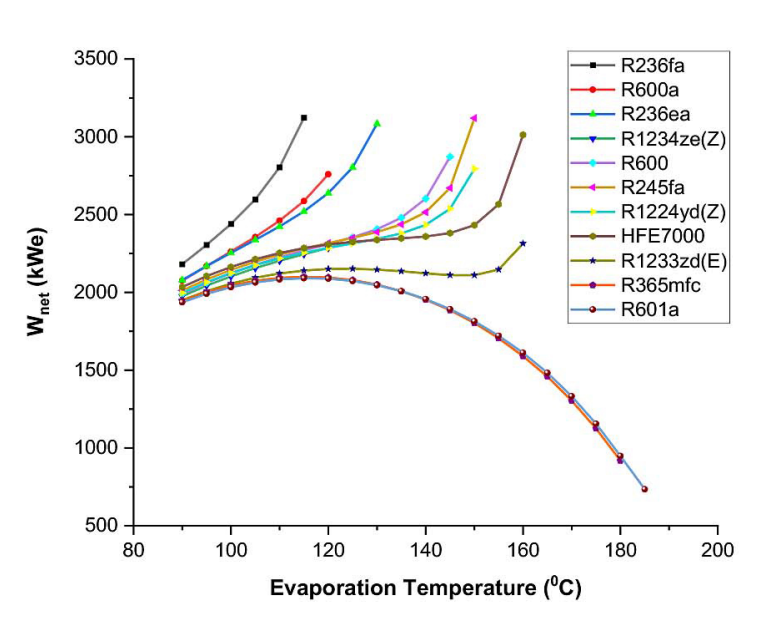

Fig. 7a. $\mathrm{W}_{\text {net }}$ and $\mathrm{T}_{\text {evap }}$ of different working fluids

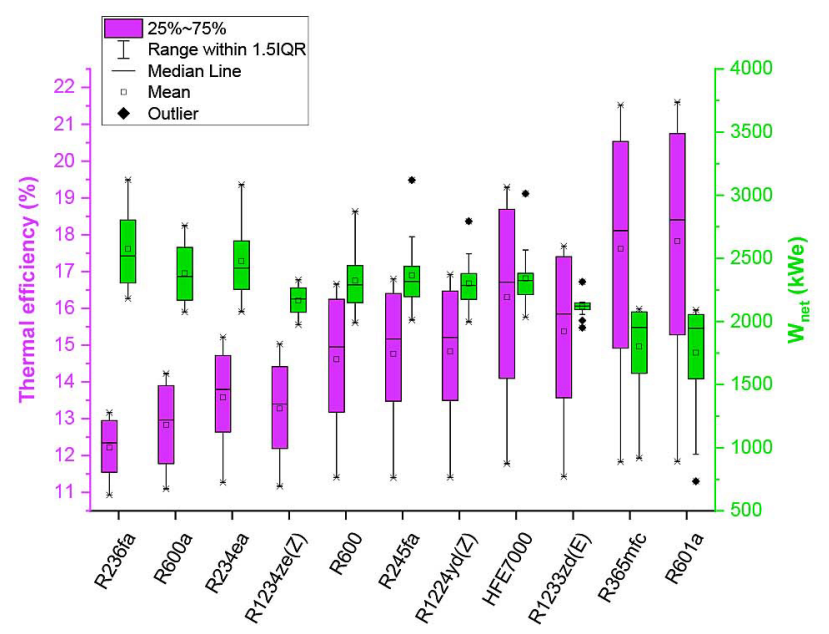

Fig. 7b. $\eta_{\text {th }}$ and $W_{\text {net }}$ of different working fluids

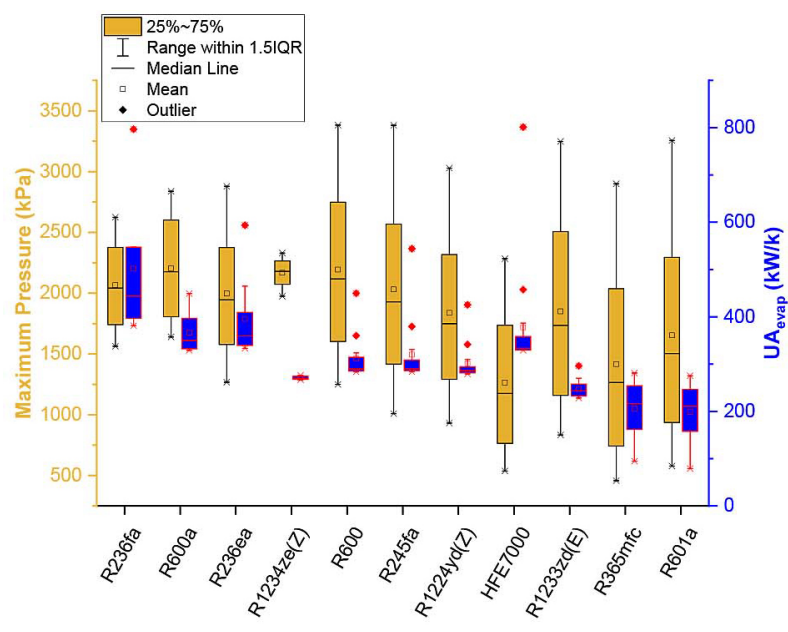

Fig. 7c. $P_{\max }$ and $U A_{\text {evap }}$ of various working fluids

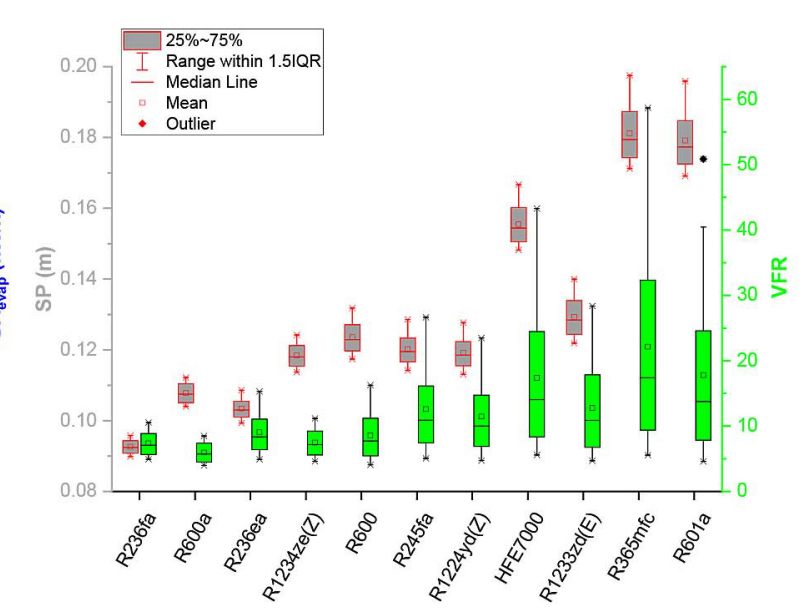

Fig. 7d. SP and VFR of various working fluids

Fig. 7. Net power output, thermal efficiency, maximum pressure, UA ${ }_{\text {evap }}$, SP and VFR of various working fluids for Recuperated ORC under subcritical conditions 


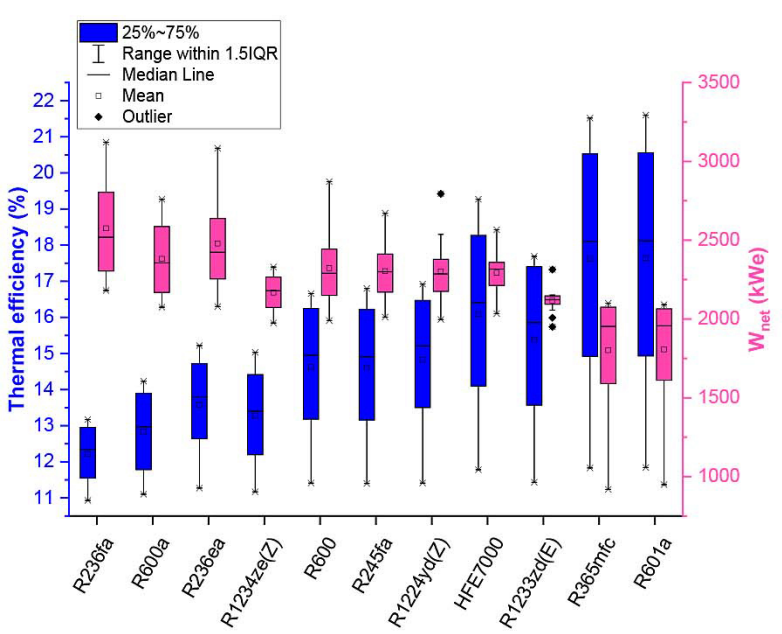

Fig. 8a. $\eta_{\text {th }}$ and $W_{\text {net }}$ of different working fluids

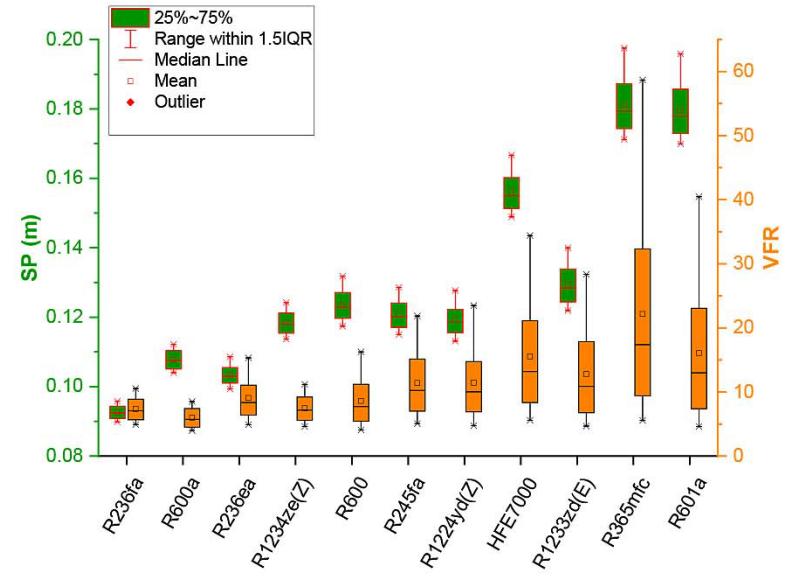

Fig. 8b. SP and VFR of various working fluids

Fig. 8. Net power output, thermal efficiency, SP and VFR of various working fluids for Recuperated ORC under superheated conditions

$\mathrm{W}_{\text {net }}$ and $\eta_{\text {th }}$, respectively. Figure $8 \mathrm{~b}$ also reveals that for superheated recuperative ORC, R236fa, R236ea and R600a have better cost-advantage compared to other working fluids.

For supercritical recuperative ORC, Figure 9a illustrate the $\mathrm{T}_{\text {evap }}$ range and their corresponding $\mathrm{W}_{\text {net }}$ for the working fluids under consideration. The trend reveals a decreasing value of $\mathrm{W}_{\text {net }}$ as $\mathrm{T}_{\text {evap }}$ increases for each working fluid, and higher $\mathrm{W}_{\text {net }}$ associated with fluids with higher critical temperature and molecular weight. R1233zd(E) is considered the most suitable for this ORC application with the highest $\mathrm{W}_{\text {net }}$ values compared to other working fluids.

Figure $9 \mathrm{~b}$ show the maximum $\eta_{\text {th }}$ and $\mathrm{W}_{\text {net }}$ of the working fluids for supercritical recuperative ORC. It is obvious R1233zd(E) (4.12MW, $17.77 \%$ ) has the highest relative $W_{\text {net }}$ and $\eta_{\text {th }}$. R1234ze(Z) (3.811MW，17.08\%) show promising potential as an alternative working fluid. Figure $9 \mathrm{c}-\mathrm{d}$ show important information from the cost-related perspective. Working fluids with high values of $W_{\text {net }}$ and $\eta_{\text {th }}$ tend to have values for $\mathrm{UA}_{\text {evap, }}$, SP and VFR, which are an indication of increased system cost. Also, R1233zd(E) is observed to have a relative advantage from both technical and economic viewpoint.

\section{Selected working fluids for subcritical, superheated and supercritical ORCs}

In this section, suitable working fluids are selected based on the analyses and discussion of working fluid characteristics for simple and recuperative ORC under subcritical, superheated and supercritical conditions in previous sections.

The primary parameters adopted in this study as selection criteria are $\mathrm{W}_{\text {net }}$, SP, and VFR. Therefore, based on the criteria defined, the following working fluids are considered more suitable for the type of ORC applied:

- Subcritical Simple ORC: R600a fluid is selected, with R236fa, R236ea and R245fa considered as a suitable alternative.

- Superheated Simple ORC: R236fa is selected, with R600a, R236ea and R245fa considered alternative.

- Supercritical Simple ORC: R1233zd(E) is selected, with R1234ze(Z) being the alternative.

- Subcritical Recuperative ORC: R236fa fluid is selected, with R236ea, and R600a considered as a suitable alternative.

- Superheated Recuperative ORC: R236fa is selected, and R236ea and R600a considered alternative.

- Supercritical Recuperative ORC: R1233zd(E), is selected, with R1234ze(Z) being alternative

\section{Exergy analysis}

In the previous subsection, performance analysis in terms of the first law of thermodynamic was performed to evaluate the different working fluid characteristics under the considered conditions. It is also important to investigate the exegetic performance. Figure 10 and 11 illustrates the exergy efficiencies of the ORC 


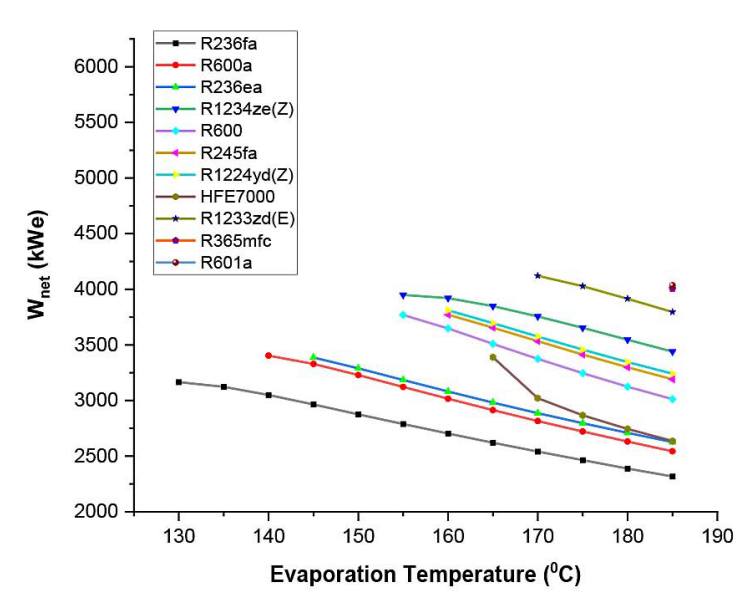

Fig. 9a. $\mathrm{W}_{\text {net }}$ and $\mathrm{T}_{\text {evap }}$ of different working fluids

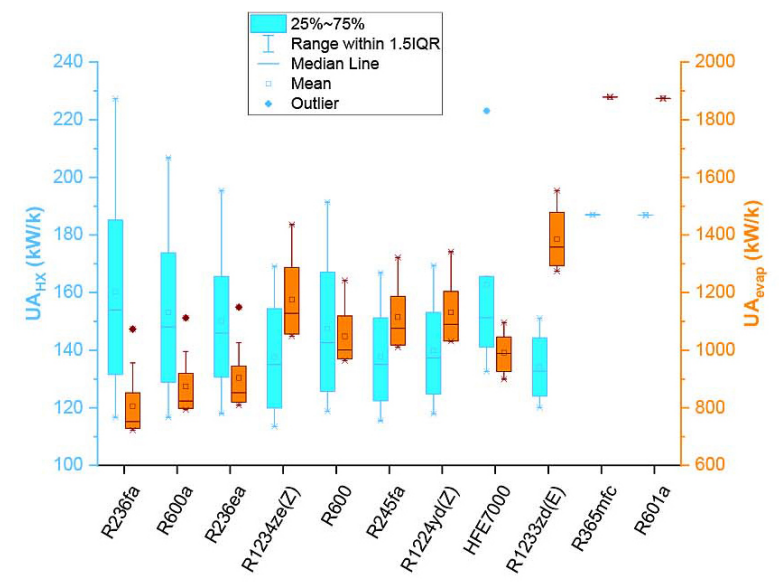

Fig. 9c. $\mathrm{UA}_{\mathrm{XH}}$ and $\mathrm{UA}_{\text {evap }}$ of various working fluids

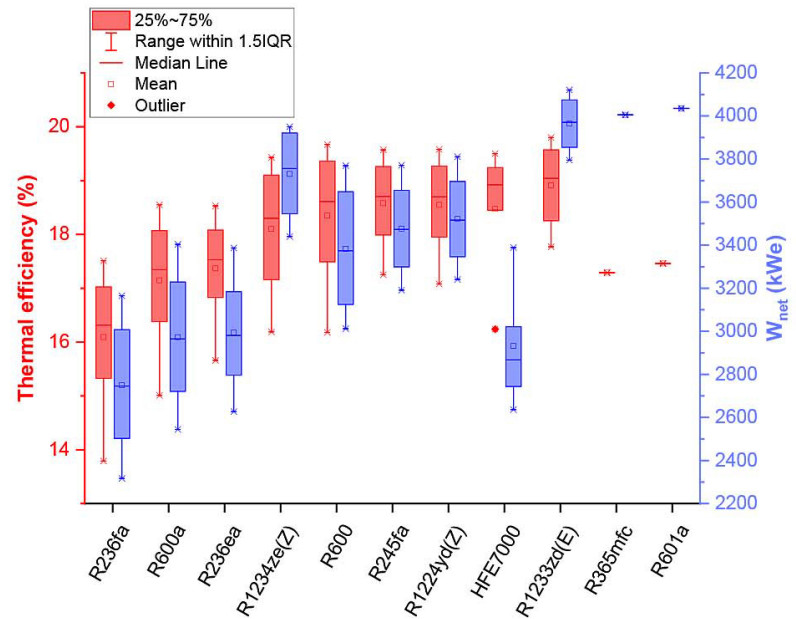

Fig. 9b. $\eta_{\text {th }}$ and $W_{\text {net }}$ of different working fluids

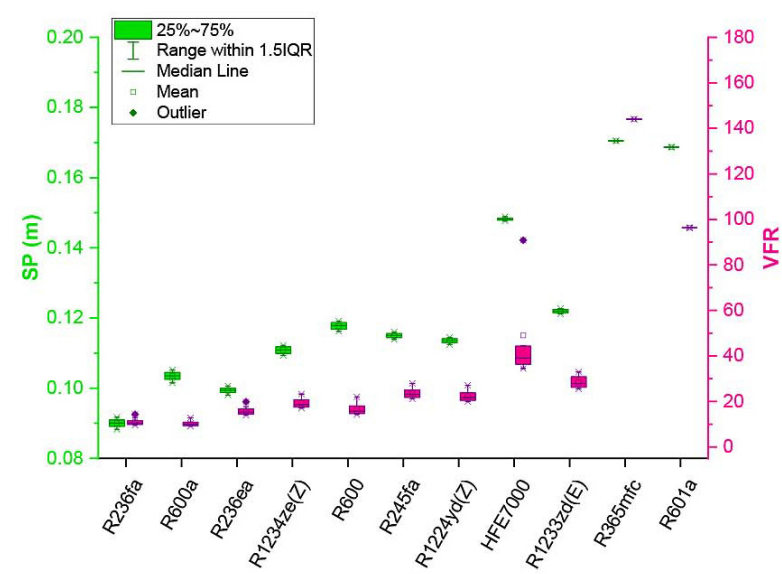

Fig. 9d. SP and VFR of various working fluids

Fig. 9. Net power output, thermal efficiency, $\mathrm{UA}_{\mathrm{XH}}, \mathrm{UA}_{\text {evap}}, \mathrm{SP}$ and VFR of various working fluids for Recuperated ORC under supercritical conditions

systems with different working fluids within the range of each fluid. Figure 10 shows the effect of ORC evaporation temperature, a variation on the overall exegetic efficiencies of the simple ORC under subcritical, superheated and supercritical conditions. It is observed that as temperature increases, the exergy efficiency of the system increases for all fluid and considered conditions. This increase is attributed to the system exegetic performance improvement as the cycle temperature and pressure increases. The supercritical ORC is observed to have slightly higher exergy efficiency compared to the subcritical cycle which is significantly higher when compared to the supercritical cycle. R236fa have the largest exegetic efficiency of around 58-62\% in both subcritical and superheated conditions, which is about $50 \%$ higher than that of R600a having the lowest relative exergy efficiency. For supercritical ORC, exergy efficiencies are comparatively low, with R1233zd(E) leading with exegetic efficiency of $36 \%$. Figure 11 illustrates the effect of a variation on the overall exergy efficiencies of the recuperative ORC operating under subcritical and superheated conditions. Analyses of results indicate that exergy efficiencies for subcritical and superheated are identical, hence analysis of superheated recuperative ORC was deliberately omitted. Results of the recuperative ORC observe a similar trend as the simple ORC, except that the exegetic efficiencies are higher owing to higher operating pressure in the supercritical ORC. Again, R236fa and R1233zd(E) are observed to have the largest exergy efficiency in subcritical and superheated conditions, respectively. 


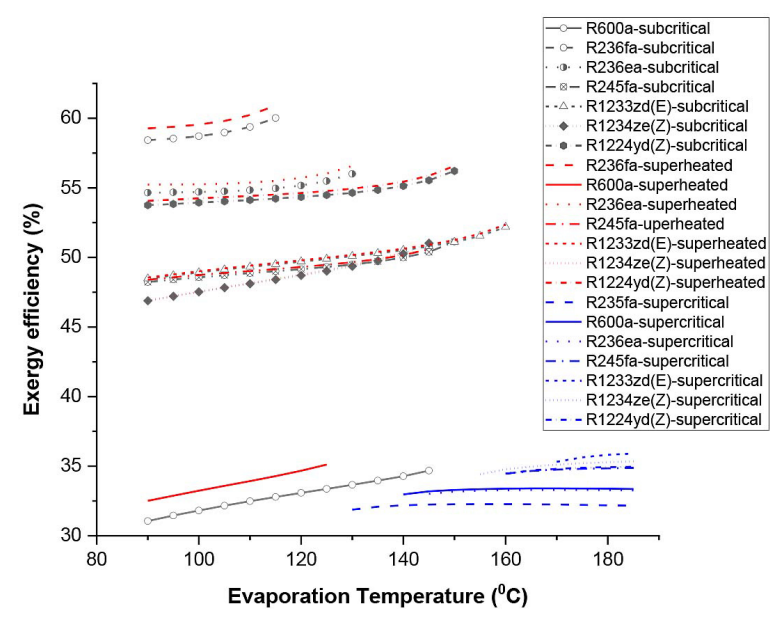

Fig. 10. $\eta_{\text {ex }}$ and $T_{\text {evap }}$ of different working fluids

\section{Exegetic analysis of system components}

An exegetic analysis of the system components is performed to assess the quality of heat transfer in a particular process and check the sustainability of the system. Important exegetic parameters like fuel depletion ratio, improvement potential, rate of exergy destruction, and irreversibility ratio were examined for both simple and recuperative ORC operating under subcritical, superheated and supercritical conditions, as shown in Table 4-5. The values of these parameters were computed at $\mathrm{T}_{\text {evap }}=115^{\circ} \mathrm{C}$ for subcritical and superheated conditions, and $\mathrm{T}_{\text {evap }}=185{ }^{\circ} \mathrm{C}$ for the supercritical condition in both simple and recuperative ORC.

As shown in Table 4-5, the major source of exergy destruction is the evaporator. This is due to the temperature difference between the heat source and the working fluids. Other main sources of exergy destruction are turbine and condenser. Results indicate that for the $\mathrm{T}_{\text {evap }}$ operating value considered, R236fa show the lowest value of total exergy destroyed for subcritical $(127.9 \mathrm{~kW})$ and superheated (119.9 kW), and R1233zd(E) for supercritical $(6282 \mathrm{~kW})$ simple ORC. A similar trend is observed for recuperative ORC, except for superheated condition where R236ea have the lowest total exergy destruction rate of $112.9 \mathrm{~kW}$.

IMP represent the largest exergy loss that can be avoided through improvement in design processes. As indicated previously, the evaporator is the major source of exergy destruction in the ORC system and should be considered for design improvement to increase performance efficiency. For example, in the R236fa subcritical simple

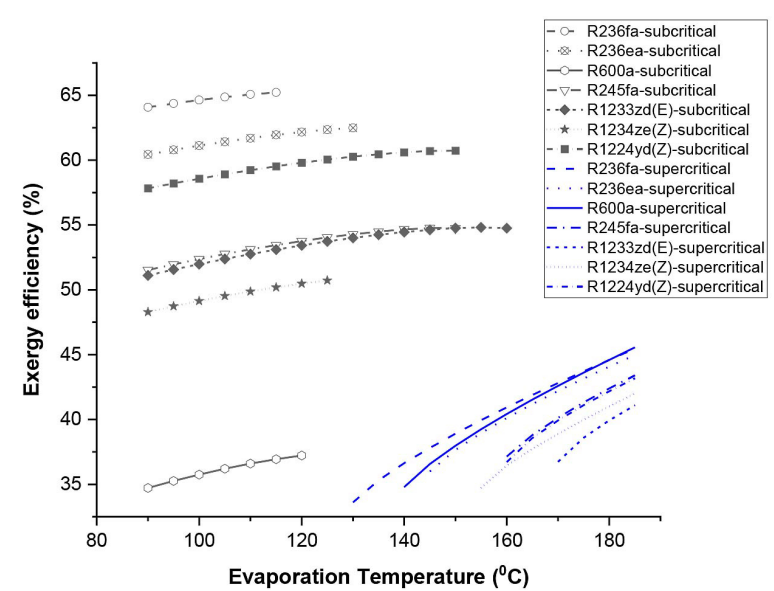

Fig. 11. $\eta_{\text {th }}$ and $T_{n e t}$ of different working fluids for for simple ORC recuperative ORC

ORC, the exergy destroyed in the evaporator is $49.93 \mathrm{~kW}$ while the IMP is $19.96 \mathrm{~kW}$ as indicated in Table 4. This implies that $39.97 \%$ of exergy destruction in the evaporator could be avoided with better design processes. For other working fluids, R600a and R245fa subcritical simple ORC indicate that $65.53 \%$ and $50.98 \%$ respectively, of exergy destroyed in the evaporator, could be avoided. R236fa, R236ea and R600a superheated simple ORC show $39.08 \%, 44.49 \%$ and $65.72 \%$ improvement potential, respectively. For the R1233zd(E), R1234ze(Z) and R1224yd(Z) supercritical simple ORC, the improvement potentials are $64.09 \%, 64.67 \%$, and $65.04 \%$, respectively.

As indicated in Table 5, evaporator improvement potential (IMP) for R600a, R236fa and R245fa subcritical recuperative ORC are $63.05 \%, 34.79 \%$, and $46.55 \%$, respectively. It is also observed that R236fa, R236ea and R600a superheated recuperative ORC, and R1233zd(E), R1234ze(Z) and R1224yd(Z) supercritical recuperative ORC, have the

Same values as their corresponding counterpart in the simple ORC discussed earlier. Thus, it can be deduced that fluids with low IMP value, like R236fa, have higher exegetic efficiency, $\eta_{\mathrm{ex}}$ and $\mathrm{W}_{\text {net }}$ values, which is an indication of better heat source utilization.

Another impotent exegetic parameter is the irreversibility ratio, which defines the ratio of exergy destroyed to the total exergy destruction in the system. Table 4-5 show that around 39-98\% of exergy destruction occurs in the evaporator. The higher rates of destructed exergy are associated with supercritical ORC. This is because of the small temperature difference between the 
Table 4. Energetic parameters of simple ORC under subcritical, superheated and supercritical

\begin{tabular}{|c|c|c|c|c|c|c|c|c|c|c|}
\hline \multirow{2}{*}{$\begin{array}{l}\text { Exegetic } \\
\text { parameter }\end{array}$} & \multirow{2}{*}{$\begin{array}{c}\text { System } \\
\text { components }\end{array}$} & \multicolumn{3}{|c|}{ Subcritical } & \multicolumn{3}{|c|}{ Superheated } & \multicolumn{3}{|c|}{ Supercritical } \\
\hline & & R600a & R236fa & R245fa & R236fa & R236ea & R600a & R1233zd(E) & R1234ze(Z) & R1224yd(Z) \\
\hline \multirow{5}{*}{$\mathrm{Ex}_{\mathrm{D}}$} & Evaporator & 73.08 & 49.93 & 78.4 & 48.34 & 71.87 & 69.45 & 6185 & 6193 & 6193 \\
\hline & Turbine & 34.14 & 41.74 & 28.42 & 37.86 & 28.83 & 31.06 & 47.94 & 44.58 & 42.58 \\
\hline & Condenser & 26.47 & 33.29 & 22.69 & 30.89 & 27.04 & 24.76 & 46.45 & 53.22 & 62.44 \\
\hline & Pump & 2.358 & 2.928 & 0.9904 & 2.849 & 1.532 & 2.284 & 2.893 & 2.614 & 2.667 \\
\hline & Total: & 136 & 127.9 & 130.5 & 119.9 & 129.3 & 127.6 & 6282 & 6294 & 6301 \\
\hline \multirow{5}{*}{ IPM (kW) } & Evaporator & 47.89 & 19.96 & 39.97 & 18.89 & 31.98 & 45.64 & 3964 & 4005 & 4028 \\
\hline & Turbine & 22.37 & 16.68 & 14.49 & 14.79 & 12.83 & 20.41 & 30.73 & 28.83 & 27.7 \\
\hline & Condenser & 17.35 & 13.31 & 11.57 & 12.07 & 12.03 & 16.27 & 29.77 & 34.41 & 40.61 \\
\hline & Pump & 1.545 & 1.171 & 0.505 & 1.113 & 0.6816 & 1.501 & 1.854 & 1.69 & 1.735 \\
\hline & Total: & 89.155 & 51.121 & 66.535 & 46.863 & 57.522 & 83.821 & 4026.354 & 4069.93 & 4098.045 \\
\hline \multirow{5}{*}{$\bar{Y}_{D}$} & Evaporator & 0.5371 & 0.3904 & 0.6007 & 0.4030 & 0.5559 & 0.5445 & 0.9845 & 0.9840 & 0.9829 \\
\hline & Turbine & 0.2509 & 0.3263 & 0.2178 & 0.3156 & 0.2230 & 0.2435 & 0.0076 & 0.0071 & 0.0068 \\
\hline & Condenser & 0.1946 & 0.2603 & 0.1739 & 0.2576 & 0.2092 & 0.1941 & 0.0074 & 0.0085 & 0.0099 \\
\hline & Pump & 0.0173 & 0.0229 & 0.0076 & 0.0238 & 0.0118 & 0.0179 & 0.0005 & 0.0004 & 0.0004 \\
\hline & Total: & 1.0 & 1.0 & 1.0 & 1.0 & 1.0 & 1.0 & 1.0 & 1.0 & 1.0 \\
\hline \multirow{5}{*}{$Y_{D}$} & Evaporator & 0.1879 & 0.2959 & 0.3417 & 0.2968 & 0.3867 & 0.1841 & 0.2080 & 0.2085 & 0.2082 \\
\hline & Turbine & 0.0878 & 0.2473 & 0.1239 & 0.2324 & 0.1552 & 0.0824 & 0.1454 & 0.1221 & 0.1388 \\
\hline & Condenser & 0.0681 & 0.1973 & 0.0989 & 0.1897 & 0.1455 & 0.0656 & 0.1409 & 0.1458 & 0.2035 \\
\hline & Pump & 0.0061 & 0.0174 & 0.0043 & 0.0175 & 0.0082 & 0.0061 & 0.0088 & 0.0072 & 0.0087 \\
\hline & Total: & 0.3499 & 0.7579 & 0.5688 & 0.7364 & 0.6956 & 0.3382 & 0.5031 & 0.4836 & 0.5592 \\
\hline
\end{tabular}

Table 5. Energetic parameters of recuperative ORC under subcritical, superheated and supercritical

\begin{tabular}{|c|c|c|c|c|c|c|c|c|c|c|}
\hline \multirow{2}{*}{$\begin{array}{c}\text { Exegetic } \\
\text { parameter }\end{array}$} & \multirow{2}{*}{$\begin{array}{c}\text { System } \\
\text { components }\end{array}$} & \multicolumn{3}{|c|}{ Subcritical } & \multicolumn{3}{|c|}{ Superheated } & \multicolumn{3}{|c|}{ Supercritical } \\
\hline & & R600a & R236fa & $\mathrm{R} 245 \mathrm{fa}$ & R236fa & R236ea & R600a & R1233zd(E) & R1234ze(Z) & $\mathrm{R} 1224 \mathrm{yd}(\mathrm{Z})$ \\
\hline \multirow{6}{*}{$\mathrm{Ex}_{\mathrm{D}}$} & Evaporator & 62.58 & 45.99 & 65.52 & 45.99 & 61.96 & 62.58 & 6216 & 6232 & 6235 \\
\hline & Turbine & 31.06 & 37.86 & 25.9 & 37.86 & 28.83 & 31.06 & 41.03 & 36.07 & 33.23 \\
\hline & Recuperator & 0.09745 & 0.1142 & 0.4976 & 0.1142 & 0.5989 & 0.09745 & 6.693 & 9.326 & 10.96 \\
\hline & Condenser & 20.64 & 26.55 & 16.85 & 26.55 & 20 & 20.64 & 2.476 & 23.52 & 22.72 \\
\hline & Pump & 2.284 & 2.849 & 0.9633 & 2.849 & 1.532 & 2.284 & 24.67 & 2.115 & 2.081 \\
\hline & Total: & 116.7 & 113.4 & 109.7 & 113.4 & 112.9 & 116.7 & 6291 & 6303 & 6304 \\
\hline \multirow{6}{*}{ IPM (kW) } & Evaporator & 39.46 & 16.0 & 30.5 & 16.0 & 23.58 & 39.46 & 5250 & 5302 & 5315 \\
\hline & Turbine & 19.59 & 13.17 & 12.06 & 13.17 & 10.97 & 19.59 & 34.66 & 30.69 & 28.33 \\
\hline & Recuperator & 0.06145 & 0.03973 & 0.2316 & 0.03973 & 0.2279 & 0.06145 & 5.653 & 7.934 & 9.341 \\
\hline & Condenser & 13.01 & 9.233 & 7.842 & 9.233 & 7.612 & 13.01 & 20.84 & 20.01 & 19.37 \\
\hline & Pump & 1.44 & 0.9908 & 0.4484 & 0.9908 & 0.5829 & 1.44 & 2.091 & 1.799 & 1.774 \\
\hline & Total: & 73.561 & 39.434 & 51.082 & 29.434 & 42.973 & 73.561 & 5313.244 & 5362.433 & 5373.815 \\
\hline \multirow{6}{*}{$\bar{Y}_{D}$} & Evaporator & 0.5364 & 0.4057 & 0.5971 & 0.4057 & 0.5487 & 0.5364 & 0.9881 & 0.9887 & 0.9891 \\
\hline & Turbine & 0.2663 & 0.3340 & 0.2361 & 0.3340 & 0.2553 & 0.2663 & 0.0065 & 0.0057 & 0.0053 \\
\hline & Recuperator & 0.0008 & 0.0010 & 0.0045 & 0.0010 & 0.0053 & 0.0008 & 0.0011 & 0.0015 & 0.0017 \\
\hline & Condenser & 0.1769 & 0.2342 & 0.1535 & 0.2342 & 0.1771 & 0.1769 & 0.0039 & 0.0037 & 0.0036 \\
\hline & Pump & 0.0196 & 0.0251 & 0.0088 & 0.0251 & 0.0136 & 0.0196 & 0.0039 & 0.0003 & 0.0003 \\
\hline & Total: & 1.0 & 1.0 & 1.0 & 1.0 & 1.0 & 1.0 & 1.0 & 1.0 & 1.0 \\
\hline \multirow{6}{*}{$Y_{D}$} & Evaporator & 0.1788 & 0.3721 & 0.3192 & 0.3023 & 0.3721 & 0.1788 & 0.2544 & 0.2703 & 0.2838 \\
\hline & Turbine & 0.0887 & 0.2488 & 0.1262 & 0.2488 & 0.1732 & 0.0887 & 0.1297 & 0.1030 & 0.1144 \\
\hline & Recuperator & 0.0003 & 0.0008 & 0.0024 & 0.0008 & 0.0036 & 0.0003 & 0.0212 & 0.0266 & 0.0377 \\
\hline & Condenser & 0.0589 & 0.1745 & 0.0821 & 0.1745 & 0.1202 & 0.0589 & 0.0779 & 0.0672 & 0.0782 \\
\hline & Pump & 0.0065 & 0.0187 & 0.0047 & 0.0187 & 0.0092 & 0.0065 & 0.0078 & 0.0060 & 0.0072 \\
\hline & Total: & 0.3332 & 0.8149 & 0.5346 & 0.7451 & 0.6783 & 0.3332 & 0.4910 & 0.4731 & 0.5213 \\
\hline
\end{tabular}


heat source and the working fluid at supercritical condition, which decreases heat transfer effectiveness in the evaporator. The turbine is the next main source of exergy destruction as demonstrated in these tables have at least $21 \%$ contribution in subcritical and superheated ORC and less than $1 \%$ in supercritical ORC.

The exegetic fuel depletion ratio represents the ratio of exergy destroyed to the inlet exergy. Table $4-5$ demonstrates that around $17-37 \%$ of the inlet exergy is destroyed in the evaporator. $8-24 \%$ and $5-20 \%$ destruction of inlet exergy occur in the turbine and condenser, respectively. The lower values indicate less exergy destruction with the component or system. From the viewpoint of the working fluids, R600a show lower values for subcritical and superheated ORC, while $\mathrm{R} 1234 \mathrm{ze}(\mathrm{Z})$ have better values for supercritical ORC.

\section{CONCLUSION}

In this study, performance analyses of simple and recuperative ORC with 11 different working fluids with the critical temperature above 150 under subcritical, superheated and supercritical conditions were evaluated to enable the selection of suitable working fluid for the ORCs. The work helps determine workable operating range and selection of working fluid for the optimal technical and economic performance of the ORCs. The following conclusions were deduced from this study:

1. To avoid turbine exit stream condensation in subcritical and superheated conditions, the evaporation temperature is chosen between 90 and a value just below the critical temperature of the working fluids. Under the supercritical condition, the evaporation is selected between values just above the critical temperature of the fluid and the heat source temperature of the ORCs.

2. Net power output, $\mathrm{W}_{\text {net }}, \mathrm{UA}_{\text {evap, }}$ SP and VFR were adopted as screening parameters for evaluation and selection of suitable working fluid for both simple and recuperative ORCs under subcritical, superheated and supercritical operations. The study concludes that within the specified conditions adopted in this work, R600, R236fa and R1233zd(E) are the suitable working fluids for subcritical, superheated and supercritical simple ORCs, respectively. Similarly, R236fa is recommended for subcritical and superheated recuperative ORC, while $\mathrm{R} 1233 \mathrm{zd}(\mathrm{E})$ is selected for supercritical recuperative ORC.

3. Exegetic efficiency of subcritical and superheated ORCs are considerably higher up to $65 \%$, compared with supercritical ORC with lower exegetic efficiency in the range of $35 \%$.

4. The evaporators are the main source of exergy destruction in the system, with up to $37 \%$ of the inlet exergy destroyed in the evaporator. These accounts for $39-98 \%$ of total exergy destroyed, with higher values particularly associated with supercritical cycles. Therefore, any improvement efforts in component design will result in a significant decrease in the exergy destruction of these components.

5. An overall exegetic improvement potential of up to $65 \%$ is possible, especially for supercritical ORC. R236fa and R1233zd(E) have the best exegetic performance for subcritical/superheated and supercritical cycles, respectively.

\section{Acknowledgement}

The author acknowledges the support of the Department of Mechanical Engineering, Faculty of Engineering, Cross River University of Technology, Calabar, Nigeria.

\section{REFERENCES}

1. Qiu, G. (2012) 'Selection of working fluids for micro-CHP systems with ORC', Renewable Energy. doi: 10.1016/j.renene.2012.06.006.

2. Tchanche, B. F., Lambrinos, G., Frangoudakis, A. and Papadakis, G. (2011) 'Low-grade heat conversion into power using organic Rankine cycles - A review of various applications', Renewable and Sustainable Energy Reviews. doi: 10.1016/j. rser.2011.07.024.

3. Chen, H., Goswami, D. Y. and Stefanakos, E. K. (2010) 'A review of thermodynamic cycles and working fluids for the conversion of low-grade heat', Renewable and Sustainable Energy Reviews. doi: 10.1016/j.rser.2010.07.006.

4. Saleh, B., Koglbauer, G., Wendland, M. and Fischer, J. (2007) 'Working fluids for low-temperature organic Rankine cycles', Energy. doi: 10.1016/j. energy.2006.07.001.

5. Yari, M. (2009) 'Performance analysis of the different organic Rankine cycles (ORCs) using dry fluids', International Journal of Exergy. doi: 10.1504/ IJEX.2009.025324. 
6. Tchanche, B.F., Papadakis, G., Lambrinos, G. and Frangoudakis, A. (2009) 'Fluid selection for a lowtemperature solar organic Rankine cycle', Applied Thermal Engineering. doi: 10.1016/j.applthermaleng.2008.12.025.

7. Lai, N.A., Wendland, M. and Fischer, J. (2011) 'Working fluids for high-temperature organic Rankine cycles', Energy. doi: 10.1016/j.energy.2010.10.051.

8. Karellas, S. and Schuster, A. (2008) 'Supercritical fluid parameters in organic rankine cycle applications', International Journal of Thermodynamics. doi: 10.5541/ijot.1034000217.

9. Maizza, V. and Maizza, A. (1996) 'Working fluids in non-steady flows for waste energy recovery systems', Applied Thermal Engineering. doi: 10.1016/1359-4311(95)00044-5.

10. Badr, O., Probert, S. D. and O'Callaghan, P. W. (1985) 'Selecting a working fluid for a Rankinecycle engine', Applied Energy. doi: 10.1016/03062619(85)90072-8.

11. Drescher, U. and Brüggemann, D. (2007) 'Fluid selection for the Organic Rankine Cycle (ORC) in biomass power and heat plants', Applied Thermal Engineering. doi: 10.1016/j.applthermaleng.2006.04.024.

12. Bruno, J.C., López-Villada, J., Letelier, E., Romera, S. and Coronas, A. (2008) 'Modelling and optimisation of solar organic rankine cycle engines for reverse osmosis desalination', Applied Thermal Engineering. doi: 10.1016/j.applthermaleng.2007.12.022.

13. Peñate, B. and García-Rodríguez, L. (2012) 'Seawater reverse osmosis desalination driven by a solar Organic Rankine Cycle: Design and technology assessment for medium capacity range', Desalination. doi: 10.1016/j.desal.2011.08.040.

14. Maraver, D., Uche, J. and Royo, J. (2012) 'Assessment of high temperature organic Rankine cycle engine for polygeneration with MED desalination: A preliminary approach', Energy Conversion and Management. doi: 10.1016/j.enconman.2011.08.013.

15. Tchanche, B.F., Lambrinos, G., Frangoudakis, A. and Papadakis, G. (2010) 'Exergy analysis of micro-organic Rankine power cycles for a small scale solar driven reverse osmosis desalination system', Applied Energy. doi: 10.1016/j.apenergy.2009.07.011.

16. Zhao, P., Wang, J., Gao, L. and Dai, Y. (2012) 'Parametric analysis of a hybrid power system using organic Rankine cycle to recover waste heat from proton exchange membrane fuel cell', International Journal of Hydrogen Energy. doi: 10.1016/j. ijhydene.2011.11.081.

17. Wang, E.H., Zhang, H.G., Zhao, Y., Fan, B.Y., Wu, Y.T. and Mu, Q.H. (2012) 'Performance analysis of a novel system combining a dual loop organic Rankine cycle (ORC) with a gasoline engine', Energy. doi: 10.1016/j.energy.2012.04.006.

18. He, M., Zhang, X., Zeng, K. and Gao, K. (2011) 'A combined thermodynamic cycle used for waste heat recovery of internal combustion engine', Energy. doi: 10.1016/j.energy.2011.10.014.

19. Katsanos, C.O., Hountalas, D.T. and Pariotis, E.G. (2012) 'Thermodynamic analysis of a Rankine cycle applied on a diesel truck engine using steam and organic medium', in Energy Conversion and Management. doi: 10.1016/j.enconman.2011.12.026.

20. Wang, H., Peterson, R., Harada, K., Miller, E., Ingram-Goble, R., Fisher, L., Yih, J. and Ward, C. (2011) 'Performance of a combined organic Rankine cycle and vapor compression cycle for heat activated cooling', Energy. doi: 10.1016/j.energy.2010.10.020.

21. Aneke, M., Agnew, B., Underwood, C. and Menkiti, M. (2012) 'Thermodynamic analysis of alternative refrigeration cycles driven from waste heat in a food processing application', International Journal of Refrigeration. doi: 10.1016/j.ijrefrig.2012.04.008.

22. Liu, H., Shao, Y. and Li, J. (2011) 'A biomass-fired micro-scale CHP system with organic Rankine cycle (ORC) - Thermodynamic modelling studies', Biomass and Bioenergy. doi: 10.1016/j.biombioe.2011.06.025.

23. Taljan, G., Verbič, G., Pantoš, M., Sakulin, M. and Fickert, L. (2012) 'Optimal sizing of biomassfired Organic Rankine Cycle CHP system with heat storage', Renewable Energy. doi: 10.1016/j. renene.2011.09.034.

24. Bao, J. and Zhao, L. (2013) 'A review of working fluid and expander selections for organic Rankine cycle', Renewable and Sustainable Energy Reviews. doi: 10.1016/j.rser.2013.03.040.

25. Roy, J.P., Mishra, M.K. and Misra, A. (2010) 'Parametric optimization and performance analysis of a waste heat recovery system using Organic Rankine Cycle', Energy. doi: 10.1016/j.energy.2010.08.013.

26. Hung, T.C. (2001) 'Waste heat recovery of organic Rankine cycle using dry fluids', Energy Conversion and Management. doi: 10.1016/S01968904(00)00081-9.

27. Desai, N.B. and Bandyopadhyay, S. (2009) 'Process integration of organic Rankine cycle', Energy. doi: 10.1016/j.energy.2009.04.037.

28. Hung, T.C., Shai, T.Y. and Wang, S.K. (1997) 'A review of organic rankine cycles (ORCs) for the recovery of low-grade waste heat', Energy. doi: 10.1016/S0360-5442(96)00165-X.

29. Hung, T.C., Wang, S.K., Kuo, C.H., Pei, B.S. and Tsai, K. F. (2010) 'A study of organic working fluids on system efficiency of an ORC using low- 
grade energy sources', Energy. doi: 10.1016/j.energy.2009.11.025.

30. Mago, P.J., Chamra, L.M., Srinivasan, K. and Somayaji, C. (2008) 'An examination of regenerative organic Rankine cycles using dry fluids', Applied Thermal Engineering. doi: 10.1016/j.applthermaleng.2007.06.025.

31. Roy, J.P., Mishra, M.K. and Misra, A. (2011) 'Performance analysis of an Organic Rankine Cycle with superheating under different heat source temperature conditions', Applied Energy. doi: 10.1016/j.apenergy.2011.02.042.

32. Liu, B.T., Chien, K.H. and Wang, C. C. (2004) 'Effect of working fluids on organic Rankine cycle for waste heat recovery', Energy. doi: 10.1016/j. energy.2004.01.004.

33. Quoilin, S., Broek, M. Van Den, Declaye, S., Dewallef, P. and Lemort, V. (2013) 'Techno-economic survey of organic rankine cycle (ORC) systems', Renewable and Sustainable Energy Reviews. doi: 10.1016/j.rser.2013.01.028.

34. Macchi, E. and Perdichizzi, A. (1981) 'Efficiency prediction for axial-flow turbines operating with nonconventional fluids', Journal of Engineering for Gas Turbines and Power. doi: 10.1115/1.3230794.

35. Angelino, G., Invernizzi, C. and Macchi, E. (1991) 'Organic Working Fluid Optimization for Space Power Cycles', in Modern Research Topics in Aerospace Propulsion. doi: 10.1007/978-1-46120945-4 16.

36. Angelino, G. and Di Paliano, P. C. (2000) 'Organic rankine cycles (ORCs) for energy recovery from molten carbonate fuel cells', Proceedings of the Intersociety Energy Conversion Engineering Conference. doi: 10.1109/IECEC.2000.870957.

37. Stijepovic, M.Z., Linke, P., Papadopoulos, A.I. and Grujic, A.S. (2012) 'On the role of working fluid properties in Organic Rankine Cycle performance', Applied Thermal Engineering. doi: 10.1016/j.applthermaleng.2011.10.057.
38. Invernizzi, C., Iora, P. and Silva, P. (2007) 'Bottoming micro-Rankine cycles for micro-gas turbines', Applied Thermal Engineering. doi: 10.1016/j.applthermaleng.2006.05.003.

39. Rayegan, R. and Tao, Y.X. (2011) 'A procedure to select working fluids for Solar Organic Rankine Cycles (ORCs)', Renewable Energy. doi: 10.1016/j.renene.2010.07.010.

40. Wang, X., Levy, E.K., Pan, C., Romero, C.E., Banerjee, A., Rubio-Maya, C. and Pan, L. (2019) 'Working fluid selection for organic Rankine cycle power generation using hot produced supercritical $\mathrm{CO}_{2}$ from a geothermal reservoir', Applied Thermal Engineering. doi: 10.1016/j.applthermaleng.2018.12.112.

41. Al-Sulaiman, F. A. (2014) 'Exergy analysis of parabolic trough solar collectors integrated with combined steam and organic Rankine cycles', Energy Conversion and Management. Elsevier Ltd, 77, pp. 441-449. doi: 10.1016/j.enconman.2013.10.013.

42. AlZahrani, A.A. and Dincer, I. (2018) 'Energy and exergy analyses of a parabolic trough solar power plant using carbon dioxide power cycle', Energy Conversion and Management. doi: 10.1016/j.enconman.2017.12.071.

43. Wu, C., Wang, S. sen, Feng, X. jia and Li, J. (2017) 'Energy, exergy and exergoeconomic analyses of a combined supercritical $\mathrm{CO} 2$ recompression Brayton/absorption refrigeration cycle', Energy Conversion and Management. Elsevier Ltd, 148(September), pp. 360-377. doi: 10.1016/j.enconman.2017.05.042.

44. Wang, E., Yu, Z., Zhang, H. and Yang, F. (no date ar) 'A regenerative supercritical-subcritical dualloop organic Rankine cycle.pdf'.

45. He, C., Liu, C., Gao, H., Xie, H., Li, Y., Wu, S. and $\mathrm{Xu}$, J. (2012) 'The optimal evaporation temperature and working fl uids for subcritical organic Rankine cycle', Energy. Elsevier Ltd, 38(1), pp. 136-143. doi: 10.1016/j.energy.2011.12.022. 